\title{
Tracing the origin of dissolved silicon transferred from various soil-plant systems towards rivers: a review
}

\author{
J.-T. Cornelis ${ }^{1}$, B. Delvaux ${ }^{1}$, R. B. Georg ${ }^{2}$, Y. Lucas ${ }^{3}$, J. Ranger ${ }^{4}$, and S. Opfergelt ${ }^{1}$ \\ ${ }^{1}$ Earth and Life Institute - Environmental Sciences, Université catholique de Louvain, Croix du Sud 2/10, \\ 1348 Louvain-la-Neuve, Belgium \\ ${ }^{2}$ Trent University, Worsfold Water Quality Centre, 1600 West Bank Dr., Peterborough, Ontario, Canada \\ ${ }^{3}$ Laboratoire Protee, Université du Sud Toulon Var, BP. 20132, 83957, La Garde, France \\ ${ }^{4}$ Biogeochemistry of forest ecosystem, INRA Centre de Nancy, 54280 Champenoux, France
}

Received: 12 July 2010 - Published in Biogeosciences Discuss.: 11 August 2010

Revised: 20 December 2010 - Accepted: 6 January 2011 - Published: 18 January 2011

\begin{abstract}
Silicon ( $\mathrm{Si}$ ) released as $\mathrm{H}_{4} \mathrm{SiO}_{4}$ by weathering of $\mathrm{Si}$-containing solid phases is partly recycled through vegetation before its land-to-rivers transfer. By accumulating in terrestrial plants to a similar extent as some major macronutrients $(0.1-10 \%$ Si dry weight), Si becomes largely mobile in the soil-plant system. Litter-fall leads to a substantial reactive biogenic silica pool in soil, which contributes to the release of dissolved $\mathrm{Si}$ (DSi) in soil solution. Understanding the biogeochemical cycle of silicon in surface environments and the DSi export from soils into rivers is crucial given that the marine primary bio-productivity depends on the availability of $\mathrm{H}_{4} \mathrm{SiO}_{4}$ for phytoplankton that requires $\mathrm{Si}$. Continental fluxes of DSi seem to be deeply influenced by climate (temperature and runoff) as well as soil-vegetation systems. Therefore, continental areas can be characterized by various abilities to transfer DSi from soil-plant systems towards rivers. Here we pay special attention to those processes taking place in soil-plant systems and controlling the Si transfer towards rivers. We aim at identifying relevant geochemical tracers of Si pathways within the soil-plant system to obtain a better understanding of the origin of DSi exported towards rivers. In this review, we compare different soilplant systems (weathering-unlimited and weathering-limited environments) and the variations of the geochemical tracers $\left(\mathrm{Ge} / \mathrm{Si}\right.$ ratios and $\left.\delta^{30} \mathrm{Si}\right)$ in DSi outputs. We recommend the use of biogeochemical tracers in combination with Si massbalances and detailed physico-chemical characterization of soil-plant systems to allow better insight in the sources and fate of $\mathrm{Si}$ in these biogeochemical systems.
\end{abstract}

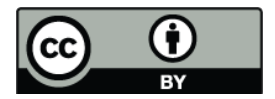

Correspondence to: J.-T. Cornelis (jean-thomas.cornelis@uclouvain.be)

\section{Introduction}

Silicon ( $\mathrm{Si}$ ) is the second most abundant element of the Earth's crust with a mean content of 28.8 wt\% (Wedepohl, 1995 ) and it occurs in a large range of minerals at the earth surface, ranging from $<0.5 \mathrm{wt} \%$ to $\sim 47 \mathrm{wt} \%$ in the pedosphere (McKeague and Cline, 1963a).

As the ultimate source, chemical weathering of silicate minerals liberates dissolved $\mathrm{Si}(\mathrm{DSi})$ as monosilicic acid $\left(\mathrm{H}_{4} \mathrm{SiO}_{4}^{0}\right)$. DSi contributes to soil formation through biogeochemical reactions on continents - such as (1) neoformation of secondary minerals (Drees et al., 1989; Wada, 1989; White, 1995), (2) adsorption onto $\mathrm{Fe}$ and $\mathrm{Al}$ (hydr)oxides (Jones and Handreck, 1963; McKeague and Cline, 1963b), and (3) uptake by plants and return of biogenic silica (BSi) on topsoil (Jones and Handreck, 1965) - and is carried from the lithosphere to the hydrosphere (Drever, 1988; Conley, 2002; Conley et al., 2006; Sommer et al., 2006). Over geological timescales ( $>10^{6}$ years), weathering of silicate minerals plays an integral role in soil development promoting the decrease in atmospheric $\mathrm{CO}_{2}$ (Rai and Kittrick, 1989; Chadwick et al., 1994; White and Blum, 1995; Berrner, 1997; Hartmann et al., 2009). Indeed, the interaction between the $\mathrm{Si}$ cycle and $\mathrm{C}$ cycle regulates the atmospheric $\mathrm{CO}_{2}$ through silicate mineral weathering (Berner, 1997), soil organic carbon sequestration in stable organo-mineral complexes (Torn et al., 1997) and the DSi nutrition of phytoplankton $\mathrm{CO}_{2}$ consumers in oceans (Conley et al., 1993; Smetacek, 1999; Tréguer and Pondaven, 2000). The leaching of DSi from soil to river strongly impacts the oceanic biogeochemical cycle of $\mathrm{Si}$, as the land-ocean flux would contribute to more than $80 \%$ of the input of DSi in the oceans (Tréguer et al., 1995).

Published by Copernicus Publications on behalf of the European Geosciences Union. 
In the terrestrial $\mathrm{Si}$ cycle, higher plants should largely contribute to the global $\mathrm{Si}$ cycle since their annual $\mathrm{BSi}$ production ranges from 1.7 to $5.6 \times 10^{12} \mathrm{~kg} \mathrm{Si} \mathrm{yr}^{-1}$ (Conley, 2002), which rivals BSi production of diatoms in the oceans $\left(6.7 \times 10^{12} \mathrm{~kg} \mathrm{Si} \mathrm{yr}^{-1}\right)$ (Tréguer et al., 1995). More recently, BSi biologically fixed was shown to be at $2.5 \times$ $10^{12} \mathrm{~kg} \mathrm{Si} \mathrm{yr}^{-1}$ (Laruelle et al., 2009), which is in the range of Conley (2002).

The global Si cycle is influenced by the type of vegetation (Bartoli, 1983; Alexandre et al., 1997; Blecker et al., 2006; Cornelis et al., 2010c), the stage of soil development (Henriet et al., 2008a, b), the climate characterized by specific moisture and temperature (Raven, 1983; White and Blum, 1995), anthropogenic actions (Conley et al., 1993, 2002), and orogenesis at the geological timescale (Raymo et al., 1988; Exley, 1998).

Despite Si (i) being a quantitatively important pool in soil, (ii) having a vital effect on plant productivity, (iii) and representing a fundamental link with the $\mathrm{C}$-cycle, the role of the type of ecosystem on the biogeochemical Si cycle and its strategic importance in the transfer of Si towards the hydrosphere are poorly studied. Sommer et al. (2006) summarize the existing knowledge on Si pools in soils and fluxes within the terrestrial biogeosphere. Conley (2002) demonstrates that biological processes in terrestrial ecosystems play an important role in global Si mass balances. However, the impact of different soil-plant systems on the continental DSi flux to the hydrosphere is not reviewed in greater detail. Therefore, the major challenges of this review are (i) to identify the Si-components and processes controlling DSi concentration in weathering environments (see Sect. 2), (ii) to assess processes governing the transfer of DSi from the soil-plant system towards rivers (see Sect. 3), (iii) to identify relevant geochemical tracers of Si pathways within the soil-plant system (see Sect. 4) and (iv) to compare different soil-plant environments and the variations of the tracers in DSi outputs (see Sect. 5).

\section{Processes controlling the dissolved $\mathrm{Si}$ concentration in weathering environments}

Silicon is a main component of soil solutions and occurs mainly in the molecular form of uncharged monomeric silicic acid $\mathrm{H}_{4} \mathrm{SiO}_{4}^{0}$ at common soil $\mathrm{pH}$ values (Iler, 1979). Silicon concentrations in soil solution can range from 0.01 to $1.99 \mathrm{mM} \mathrm{Si}$ (Karathanasis, 2002), but more commonly from 0.1 to $0.6 \mathrm{mM}$ (Faure, 1991; Epstein, 2001).

Silicon hardly forms complexes with dissolved organic matter, but can combine with Al along the whole soil solution range of $\mathrm{pH}$ to form colloidal Al-Si polymers (Doucet et al., 2001). The aqueous chemistry of $\mathrm{Si}$ is regulated by a number of linked processes (Fig. 1): (i) dissolution of the $\mathrm{Si}$ containing solid phases, (ii) precipitation and neoformation of authigenic Si-constituents, (iii) Si adsorption/desorption on various solid phases, (iv) $\mathrm{Si}$ absorption by vegetation and micro-organisms, (v) preservation of stable $\mathrm{Si}$ forms in the profile and (vi) external atmospheric inputs. The continental Si cycle can be represented by five components (Fig. 1): soil solution, groundwater, rivers, biomass and soils, which are linked to the global Si cycle by two other major reservoirs (oceans and atmosphere).

\subsection{Solubility of Si-minerals}

In rocks, $\mathrm{Si}$ ranges from more than $46.5 \%$ (e.g. orthoquartzite) to $23 \%$ in basic rocks (e.g. basalt) to trace amounts in carbonaceous rocks (e.g. limestones and carbonatites) (Monger and Kelly, 2002). In derived soils, Si ranges from $46.0 \%$ in silcretes to $7.9 \%$ in petrocalcic horizons, and even lower in some highly weathered Oxisols such as bauxites or ferricretes (Monger and Kelly, 2002). Soils mainly contain Si as silica minerals, primary silicates and secondary silicates, especially phyllosilicates (Iler, 1979). More than 100 relatively common crystallized silicates have been listed in soils in addition to an important variety of amorphous forms of inorganic and biogenic silica as well as poorly-crystalline silicates (McKeague and Cline, 1963a) (Fig. 2).

Primary minerals inherited in soils are concentrated in sand and silt fractions $(50-2000 \mu \mathrm{m}$ and $2-50 \mu \mathrm{m}$, respectively). Conversely, secondary minerals are concentrated in the clay fraction $(<2 \mu \mathrm{m})$ as a result of pedogenic processes (Allen and Hajek, 1989), involving phyllosilicates and Al-Fe (hydr)oxides. As shown in Fig. 2, Si also occurs as poorly crystalline phases such as short-range ordered silicates (allophane and imogolite), and micro-crystalline phases such as authigenic quartz and chalcedony.

The amorphous silica (ASi) pool of soil has both a pedogenic and biogenic (BSi) origin. Pedogenic ASi corresponds to the non-crystalline inorganic fraction such as opalA formed under supersaturated soluble Si levels (Drees et al., 1989), volcanic glasses and opal coatings on secondary minerals (McKeague and Cline, 1963b; Chadwick et al., 1987). The formation of ASi coatings (silcretes, cements) on other mineral surfaces as a secondary product of weathering is widely recognized in soils and sediments (Dove, 1995; Basile-Doelsch et al., 2005). On the other hand, the biogenic $\mathrm{Si}$ pool in soil comprises phytoliths (opal-A polymerized in leaves) and remnants of micro-organisms (microbial and protozoic Si) (Sauer et al., 2006; Sommer et al., 2006; Aoki et al., 2007). Biogenic opal is a ubiquitous and significant component of soils developed under a wide range of environmental conditions, while inorganic pedogenic opal is formed only under specific physico-chemical soil conditions (Drees et al., 1989). 


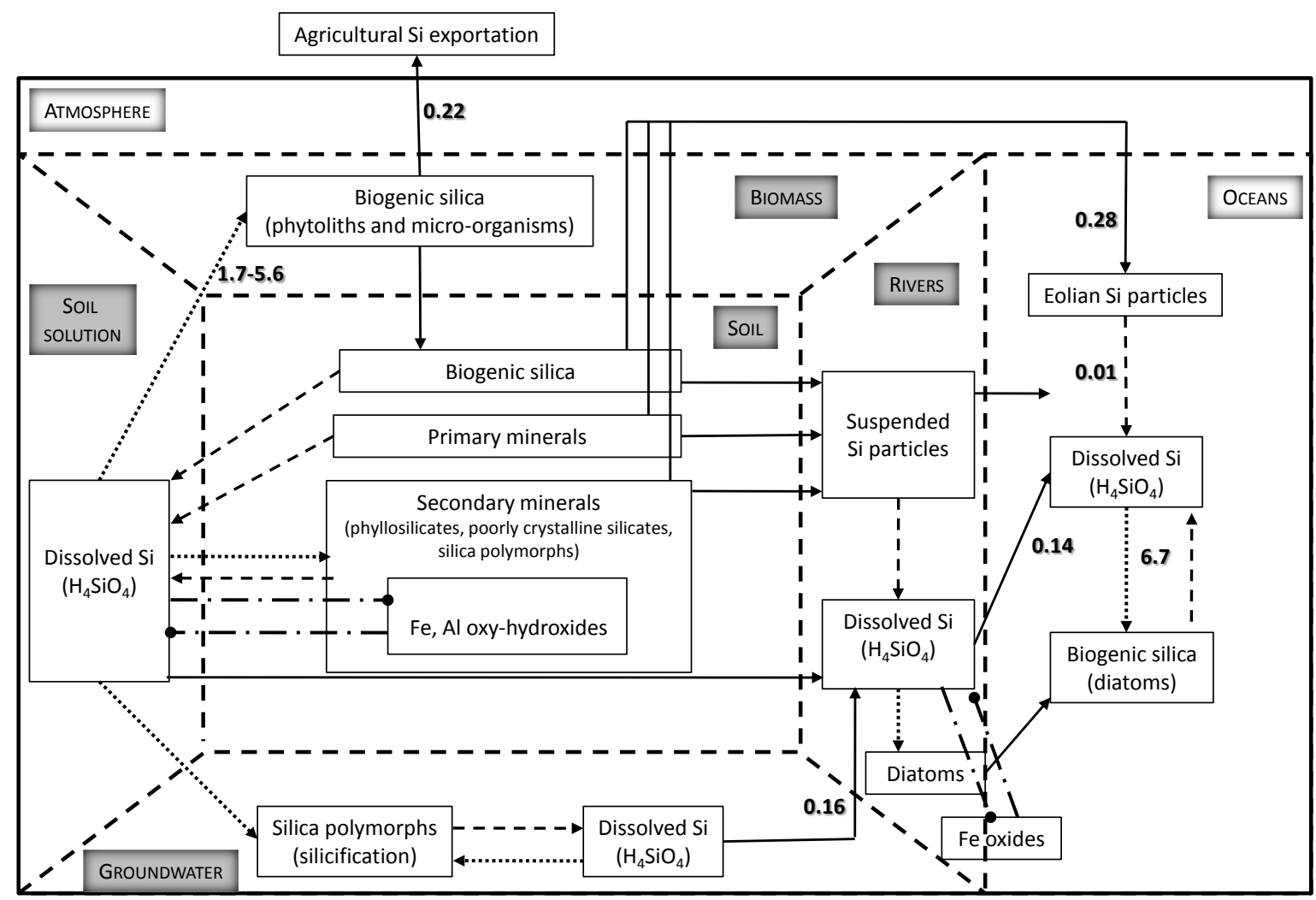

Fig. 1. Biogeochemical Si cycle on continents (compartments modified from Basile-Doelsch et al., 2005). Solid line: transport; dashed line: dissolution; small dotted line: neoformation/precipitation; pointed-dotted line: adsorption/desorption. Numbers on arrows show inter-pool Si transfers in $10^{12} \mathrm{~kg} \mathrm{Si} \mathrm{yr}^{-1}$ (Tréguer et al., 1995; Matichenkov and Bocharnikova, 2001).

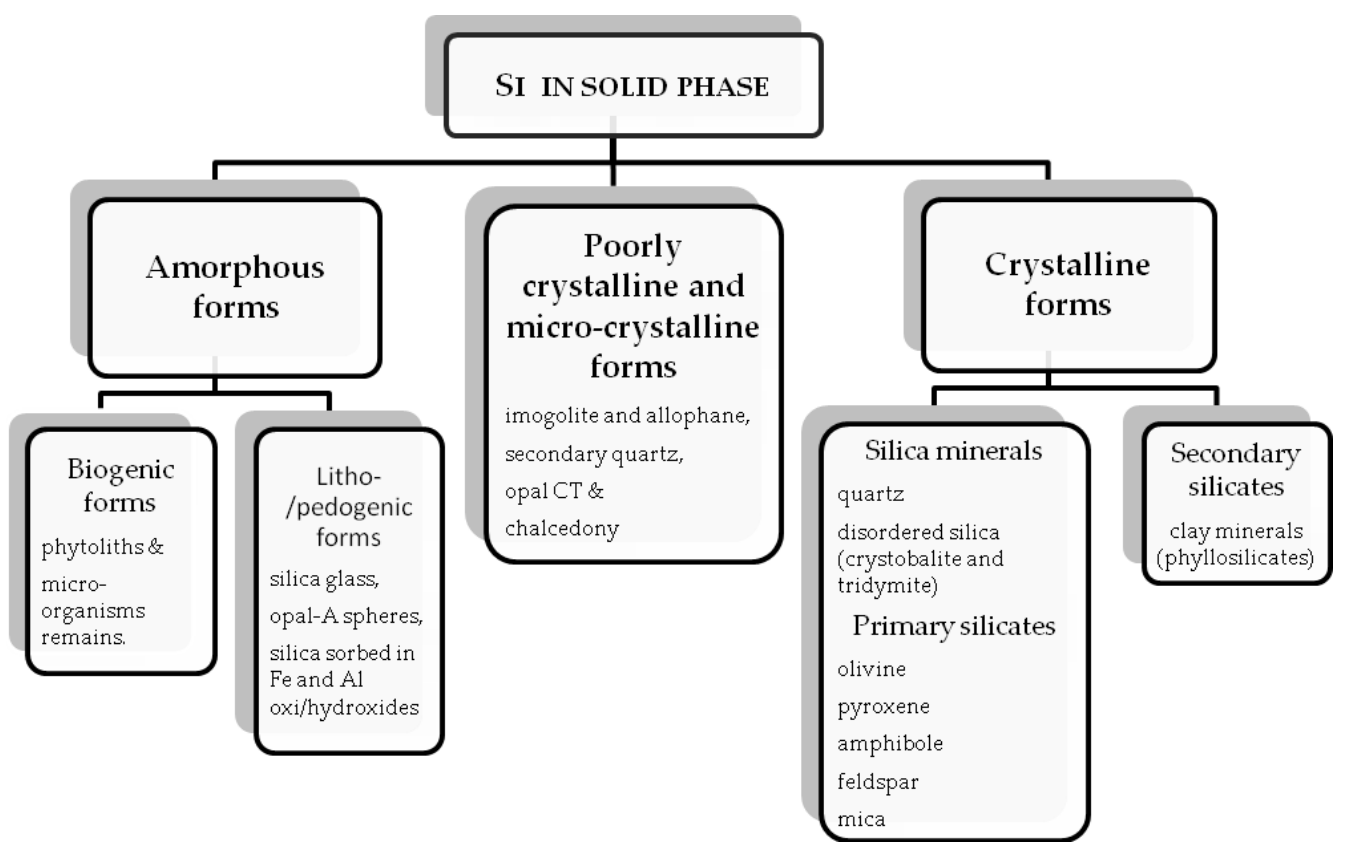

Fig. 2. Classification of solid Si compounds in the soil (modified from Sauer et al., 2006). 


\subsubsection{Silica}

In soils, the solubility of amorphous silica is higher (1.8$2 \mathrm{mM} \mathrm{Si})$ than quartz $(0.10-0.25 \mathrm{mM} \mathrm{Si})$ since solubility is a function of the packing density of the silica tetrahedral and long-range crystal order (Iler, 1979; Lindsay, 1979; Drees et al., 1989). Quartz, abundant in both residual and transported parent material, is highly stable and thermodynamically more resistant to weathering, being the last mineral to crystallize from magma (Drees et al., 1989; Monger and Kelly, 2002). The dissolution of silica polymorphs undergoes hydrolysis at $\mathrm{pH}<9$ by the overall reaction:

$\mathrm{SiO}_{2(\mathrm{~s})}+2 \mathrm{H}_{2} \mathrm{O}=\mathrm{H}_{4} \mathrm{SiO}_{4}^{0}$

The solubility of biogenic silica is equivalent to that of vitreous silica $(1.8 \mathrm{mM} \mathrm{Si})$ and is 17 times higher than quartz (Fraysse et al., 2006). The rate at which $\mathrm{Si}$ is released from plant litter is independent of cellulose hydrolysis, which suggests that most of the litter-Si is contained in the phytoliths as a pure "inorganic" pool, and not complexed with organic matter (Fraysse et al., 2010). The plants need to find a balance between cellulose, lignin and $\mathrm{Si}$ incorporation to be rigid but still flexible. Thus, it could be assumed that aquatic macrophyte $\mathrm{Si}$ metabolism is closely linked with cellulose and lignin metabolism (Schoelynck et al., 2010).

Despite the various morphologies and different specific surface area of phytoliths, mass-normalized dissolution rates are similar among all types of plant species (horsetail, larch, elm and fern; Fraysse et al., 2009) and these dissolution rates are an order of magnitude higher than those for typical soil clay minerals. The sorption of $\mathrm{Al}$ and other bi- and trivalent metals $\left(\mathrm{Fe}^{3+}, \mathrm{Zn}^{2+}\right.$ and $\left.\mathrm{Cu}^{2+}\right)$ affects the surface properties of the silica polymorphs and decreases their rates of dissolution (Dove, 1995; McKeague and Cline, 1963a). So is the solubility of pine phytoliths for instance three times lower than the one of beech phytoliths because of a higher Al substitution (Bartoli, 1985).

Dissolution rates of amorphous silica should simply increase linear with undersaturation. However, Dove et al. (2008) observe that the dissolution rates of amorphous silica exhibit an exponential dependence on electrolytes (alkaline or alkaline earth cations) like their crystalline counterpart, quartz.

The solubility of silica polymorphs, both crystalline and amorphous, is essentially constant between the $\mathrm{pH}$ limits of 2 and 8.5, but increases rapidly near $\mathrm{pH} 9$ since the weakly acidic $\mathrm{H}_{4} \mathrm{SiO}_{4}$ dissociates appreciably such that the first reaction is written (Dove, 1995):

$\mathrm{H}_{4} \mathrm{SiO}_{4}=\mathrm{H}_{3} \mathrm{SiO}_{4}^{-}+\mathrm{H}^{+}$

This reaction is an important buffer for some natural systems and, as a result, only environments with unusually lowsilica status, like carbonatites and serpentinites, can reach a $\mathrm{pH}$ above the first $\mathrm{pK}$ of silicic acid $\left(\mathrm{pK}_{\mathrm{a} 1}=9.82\right.$ at $\left.25^{\circ} \mathrm{C}\right)$.
The Si-polymeric species become stable at $\mathrm{pH} \sim 9$ (Knight and Kinrade, 2001; Dietzel, 2000, 2002).

\subsubsection{Silicate minerals}

The weathering rates of silicate minerals are important for soil development, soil buffering capacities related to acidic deposition, control of carbon cycle and cycling of many inorganic elements which are critical for soil fertility (White, 1995). The weathering rate of a mineral in a given environment can be considered as a function of intensity factors (temperature, moisture, $\mathrm{pH}$ and $\mathrm{Eh}$ ) and capacity factors (specific surface area and nature of the mineral) (McKeague and Cline, 1963a). This results in a sequence of increasing stability of soil minerals (Table 1) from the least stable primary minerals to the secondary phyllosilicates (e.g. kaolinite, allophane, $\mathrm{Al}$ and $\mathrm{Fe}$ (hydr)oxides) (Nagy, 1995).

Since relatively large $\mathrm{K}^{+}, \mathrm{Na}^{+}$and $\mathrm{Ca}^{2+}$ ions balance the charge deficit, feldspar weathers more rapidly than quartz (McKeague and Cline, 1963a; White, 1995) to yield secondary minerals and silicic acid as for example:

$$
\begin{aligned}
& 2 \mathrm{KAlSi}_{3} \mathrm{O}_{8}+2 \mathrm{CO}_{2}+11 \mathrm{H}_{2} \mathrm{O} \rightarrow \mathrm{Al}_{2} \mathrm{Si}_{2} \mathrm{O}_{5}(\mathrm{OH})_{4} \\
& +2 \mathrm{~K}^{+}+2 \mathrm{HCO}_{3}^{-}+4 \mathrm{H}_{4} \mathrm{SiO}_{4}
\end{aligned}
$$

The mineral weathering rate depends on mainly chemical equilibrium, where any processes consuming free silicic acid, e.g. secondary precipitates, adsorption and uptake by vegetation (Eq. 3), can considerably accelerate mineral dissolution (Exley, 1998; Dove, 1995; Street-Perrott and Barker, 2008). The high concentration of low molecular organic acids in the organic horizons is likely to promote primary and secondary minerals weathering through complexation and acid attack (Bennet et al., 1991; Barman et al., 1992; Oliva et al., 1999; Giesler et al., 2000; Gérard et al., 2002; Cornelis et al., 2010a).

\subsection{Neoformation and precipitation of Si-minerals}

The Si concentration in soil solutions strongly depends on equilibrium to secondary phases, and is thus strongly related to the stage of soil development as influenced by age, climate and parent material (Rai and Kittrick, 1989; Karathanasis, 2002). Indeed, at fixed $\mathrm{pH}$, smectite stability in Vertisols is associated with a relatively high concentration of aqueous $\mathrm{H}_{4} \mathrm{SiO}_{4}(\sim 1.6 \mathrm{mM} \mathrm{Si})$ whereas kaolinite, predominantly occurring in Ferralsols, Acrisols, and Lixisols, is associated with a low $\mathrm{H}_{4} \mathrm{SiO}_{4}$ concentration $(0.03 \mathrm{mM} \mathrm{Si}$ ) (Rai and Kittrick, 1989).

Besides the fact that $\mathrm{Al}$ coatings suppresses the solubility of silica, the decrease in $\mathrm{Al}$ activity in soil solution would enhance the dissolution of secondary Al-containing minerals and, hence, release of $\mathrm{H}_{4} \mathrm{SiO}_{4}$ in soil solution (McKeague and Cline, 1963a; Rai and Kittrick, 1989). The formation of short-range ordered $\mathrm{Al}-\mathrm{Si}$ compounds occurs in 
Table 1. Mineral weathering sequence (Goldich, 1938) and type of minerals as indicators of relative degree of soil development (the higher the number, the higher the degree of soil development) (Rai and Kittrick, 1989; Nagy, 1995; Allen and Hajek, 1989).

\begin{tabular}{|c|c|c|c|}
\hline $\begin{array}{l}\text { Relative degree of } \\
\text { soil development }\end{array}$ & Stability & Minerals* & Formula \\
\hline 13 & STABLE & $\begin{array}{l}\text { Anatase } \\
\text { RUTILE } \\
\text { CORUNDUM }\end{array}$ & $\begin{array}{l}\mathrm{TiO}_{2} \\
\mathrm{TiO}_{2} \\
\mathrm{Al}_{2} \mathrm{O}_{3}\end{array}$ \\
\hline 12 & & $\begin{array}{l}\text { Hematite } \\
\text { Goethite }\end{array}$ & $\begin{array}{l}\alpha-\mathrm{Fe}_{2} \mathrm{O}_{3} \\
\alpha-\mathrm{FeOOH}\end{array}$ \\
\hline 11 & & $\begin{array}{l}\text { Gibbsite } \\
\text { Allophane }\end{array}$ & $\begin{array}{l}\mathrm{Al}(\mathrm{OH})_{3} \\
\left(\mathrm{Al}_{2} \mathrm{O}_{3}\right)\left(\mathrm{SiO}_{2}\right)_{1.3} \cdot 2.5\left(\mathrm{H}_{2} \mathrm{O}\right)\end{array}$ \\
\hline 10 & & $\begin{array}{l}\text { Kaolinite } \\
\text { Halloysite }\end{array}$ & $\mathrm{Si}_{2} \mathrm{Al}_{2} \mathrm{O}_{5}(\mathrm{OH})_{4}$ \\
\hline 9 & & Smectites & $\mathrm{M}_{\mathrm{X}} \mathrm{Si}_{4}\left(\mathrm{Al}_{2-\mathrm{x}} \mathrm{Mg}_{\mathrm{x}}\right) \mathrm{O}_{10}(\mathrm{OH})_{2}$ \\
\hline 8 & & $\begin{array}{l}\text { 2:1 layer silicates } \\
\text { Vermiculite }\end{array}$ & $(\mathrm{Mg}, \mathrm{Fe})_{3}\left(\mathrm{Al}_{\mathrm{x}} \mathrm{Si}_{4-\mathrm{x}}\right) \mathrm{O}_{10}(\mathrm{OH})_{2} 4 \mathrm{H}_{2} \mathrm{OMg}_{\mathrm{x}}$ \\
\hline 7 & & $\begin{array}{l}\text { MUSCOVITE } \\
\text { Illite }\end{array}$ & $\begin{array}{l}\mathrm{KAl}_{2}\left(\mathrm{Si}_{3} \mathrm{Al}\right) \mathrm{O}_{10}(\mathrm{OH})_{2} \\
\mathrm{~K}_{\mathrm{X}} \mathrm{Al}_{2}\left(\mathrm{Si}_{4-\mathrm{x}} \mathrm{Al}_{\mathrm{X}}\right) \mathrm{O}_{10}(\mathrm{OH})_{2}\end{array}$ \\
\hline 6 & & QUARTZ & $\mathrm{SiO}_{2}$ \\
\hline 5 & & FELDSPARS & $\mathrm{KAlSi}_{3} \mathrm{O}_{8}, \mathrm{NaAlSi}_{3} \mathrm{O}_{8}-\mathrm{CaAl}_{2} \mathrm{Si}_{2} \mathrm{O}_{8}$ \\
\hline 4 & & BIOTITE & $\mathrm{K}(\mathrm{Mg}, \mathrm{Fe})_{3}\left(\mathrm{Si}_{3} \mathrm{Al}\right) \mathrm{O}_{10}(\mathrm{OH})_{2}$ \\
\hline 3 & & $\begin{array}{l}\text { OLIVINE } \\
\text { HORNBLENDE } \\
\text { PYROXENE }\end{array}$ & $\begin{array}{l}(\mathrm{Mg}, \mathrm{Fe})_{2} \mathrm{SiO}_{4} \\
\mathrm{Ca}_{2} \mathrm{Na}(\mathrm{Mg}, \mathrm{Fe})_{4}(\mathrm{Al}, \mathrm{Si})_{8} \mathrm{O}_{22}(\mathrm{OH}, \mathrm{F})_{2} \\
\mathrm{Ca}(\mathrm{Mg}, \mathrm{Fe}, \mathrm{Al})(\mathrm{Si}, \mathrm{Al})_{2} \mathrm{O}_{6}\end{array}$ \\
\hline 2 & & $\begin{array}{l}\text { CALCITE } \\
\text { DOLOMITE } \\
\text { APATITE }\end{array}$ & $\begin{array}{l}\mathrm{CaCO}_{3} \\
\mathrm{Ca}, \mathrm{Mg}\left(\mathrm{CO}_{3}\right)_{2} \\
\mathrm{Ca}_{5}(\mathrm{~F}, \mathrm{Cl}, \mathrm{OH})\left(\mathrm{PO}_{4}\right)_{3}\end{array}$ \\
\hline 1 & UNSTABLE & $\begin{array}{l}\text { GYPSUM } \\
\text { HALITE }\end{array}$ & $\begin{array}{l}\mathrm{CaSO}_{4}{ }_{2} \mathrm{H}_{2} \mathrm{O} \\
\mathrm{NaCl}\end{array}$ \\
\hline
\end{tabular}

* Primary minerals are capitalized.

horizons with $\mathrm{pH}\left(\mathrm{H}_{2} \mathrm{O}\right)$ values $>5.0$ (Wada, 1989). Moreover the precipitation of $\mathrm{H}_{4} \mathrm{SiO}_{4}$ with $\mathrm{Al}$ hydroxides forms hydroxialuminosilicates (HAS), which might be considered as amorphous precursors to imogolite (Exley, 1998; Doucet et al., 2001). In environments with very active humus, characterized by high decomposition rates, the formation of Al-organic matter complex inhibits the formation of allophane and imogolite and favours formation of opaline silica (Huang, 1991).

If the ecological and climatic conditions favour evapotranspiration, the $\mathrm{H}_{4} \mathrm{SiO}_{4}$ concentration of some soil solutions might exceed the solubility of ASi defined as $2.1 \mathrm{mM} \mathrm{Si}$ at $25^{\circ} \mathrm{C}$ (Alexander et al., 1953; Monger and Kelly, 2002), and promote the formation of opal-A, opal-CT and microquartz (Chadwick et al., 1987). In fact, biogenic opal-A plays an important role in the genesis of the siliceous cements of hardpans and silcretes (Clarke, 2003). The dissolution of opal-A and reprecipitation to opal-CT, which in turn is transformed into secondary micro-crystalline quartz, may be mediated by condensation reactions of silica polymers onto metal hydroxides (Drees et al., 1989; Monger and Kelly, 2002). Moreover, nano-colloidal silica particles $(<3 \mathrm{~nm}$, equivalent to 300 silica monomer units) can be important for the precipitation of $\mathrm{SiO}_{2}$ (Conrad et al., 2007). The partial dissolution of the biogenic opal-A in topsoil also provides DSi for sequestration in secondary minerals (clay neoformation and Si adsorption) in upper soil horizons (Lucas et al., 1993; Lucas, 2001; Michalopoulos and Aller, 2004; Barré et al., 2009; Opfergelt et al., 2010). 
It must be emphasized that the pedogenic formation of secondary Si-containing minerals (phyllosilicates, silica and short-range ordered aluminosilicates) is strongly influenced by $\mathrm{Si}$ activity in soil solution which depends on (i) parent material as the ultimate and readily source of $\mathrm{H}_{4} \mathrm{SiO}_{4}$, and (ii) climate providing water for weathering and preventing intensive leaching of $\mathrm{H}_{4} \mathrm{SiO}_{4}$ (Jackson et al., 1948; Dove, 1995; White, 1995; Berner, 1995; Gérard et al., 2002; Monger and Kelly, 2002). Climate (mainly moisture and temperature) plays thus a major role in the $\mathrm{Si}$ distribution in soils: worldwide, a large range of soil types can derive from the same rock (climosequence). Moisture is influenced by precipitation intensity and seasonality, humidity, evapotranspiration, runoff and infiltration. Thermal effects, described by the Arrhenius relationship, include average air temperatures, seasonal temperature variations, and thermal gradients in soils (White, 1995). Generally, we can schematize the world weathering system and the distribution of $\mathrm{Si}$ containing minerals as a function of climate (Pédro, 1968, 1984; Millot, 1979; IUSS WRB, 2006; Legros, 2007).

With regard to Si-bearing minerals and based on a fixed time scale, the rough result of pedogenesis is firstly dependent on the rainfall, which determines both weathering rates and element concentrations in the soil solutions. In dry deserts, the weathering of minerals is zero or very low. In Mediterranean and dry tropical climates, Si leaching is low, soil solutions are $\mathrm{Si}$-concentrated so that authigenic $\mathrm{Si}$ bearing minerals are Si-rich clay from the smectite group (Si/Al ratio around 2) or, over Al-poor rocks, opal and quartz. In tropical humid and equatorial areas, as well in high rainfall temperate areas, Si leaching is high, soil solutions are depleted in dissolved $\mathrm{Si}$ so that authigenic Si-bearing minerals are $\mathrm{Si}$-poor clays from the kaolinite group ( $\mathrm{Si} / \mathrm{Al}$ ratio around 1 ), or none as for bauxite genesis. In cold temperate climate, the rate of weathering is restricted inducing secondary Si-bearing minerals derived from limited transformation of existing minerals in rocks (micas) into new species (vermiculites), when in cold climates primary clays (illites and chlorites) are directly inherited from the parent material (detrital origin) without forming new minerals. As most of secondary Si-bearing minerals are clay minerals, their neoformation also depends on $\mathrm{Al}$ disponibility, so that where $\mathrm{Al}$ can be sequestered and leached out of the soil as organometallic compounds, no precipitation of secondary minerals occurs and podzol formation begins (Lucas, 2001). As a consequence of the pedogenesis, the soil type influences the form and the content of Si (McKeague and Cline, 1963a). A convergence from both climate and time leads to highly weathered tropical soils whatever the parent material, except likely for detritical parent material deriving into arenosol.

\subsection{Si adsorption on solid phases}

The monosilicic acid can be withdrawn from soil solution through the adsorption onto a variety of solid phases in soils
(McKeague and Cline, 1963b). Although little Si adsorption has been reported onto secondary clay minerals (Siever and Woodford, 1973), Fe and Al oxides are the main soil components with a significant capacity for Si adsorption (Beckwith and Reeve, 1963; McKeague and Cline, 1963b; Cornell and Schwertmann, 1996).

The adsorption of monosilicic acid by oxides depends on (i) $\mathrm{pH}$ with an increase from $\mathrm{pH} 4$ to $\mathrm{pH} 9$, and (ii) metal type, e.g. aluminium oxides were found to be more effective in adsorbing monosilicic acid than iron oxides (Jones and Handreck, 1963, 1965, 1967; McKeague and Cline, 1963b). $\mathrm{H}_{4} \mathrm{SiO}_{4}$ interacts with $\mathrm{Fe}$-oxide surface $\mathrm{OH}$ groups through ligand exchange to form silicate bi-dendate innersphere complex (Parfitt, 1978; Pokrovsky et al., 2003; Hiemstra et al., 2007). Silicic acid is specifically adsorbed onto secondary oxides, with a higher amount adsorbed onto synthetic shortrange ordered ferrihydrite compared to crystalline goethite (Delstanche et al., 2009). On Fe oxide surfaces, polysilicic acid might be formed by specific interaction with orthosilicic acid (Dietzel, 2002). Since iron oxides are ubiquitous in soils (Schwertmann and Taylor, 1989), they partly control the concentration of $\mathrm{H}_{4} \mathrm{SiO}_{4}$ in the aqueous phase (McKeague and Cline, 1963b; Opfergelt et al., 2009).

\subsection{Si recyling by vegetation}

Silicon is taken up by terrestrial plants from soil solution as uncharged monosilicic acid $\left(\mathrm{H}_{4} \mathrm{SiO}_{4}^{0}\right)$, transported into the xylem (Casey et al., 2003) and mainly deposited in transpiration sites where polymerization of hydrated amorphous silica occurs to form phytoliths $\left(\mathrm{SiO}_{2} \mathrm{nH}_{2} \mathrm{O}\right.$; BSi) (Jones and Handreck, 1965, 1967; Raven, 1983; Sangster and Hodson, 1986). $\mathrm{SiO}_{2}$ precipitation occurs mainly in epidermis of shoots but can also occur in the vascular system and endodermis of roots (Raven, 1983; Lux et al., 2003a, b). Silicon seems to be unavailable for retranslocation once amorphous silica polymerizes in aerial parts of the plants (Raven, 1983). Phytoliths are released in the topsoil through organic matter decomposition (Smithson, 1956). The biomineralization of amorphous silica seems to be restricted to some plant families (Epstein, 1999; Hodson et al., 2005) and appear in various shapes depending on the location of Si deposits and plant species (Carnelli et al., 2001, 2004). The International Code for Phytolith Nomenclature (ICPN) has been proposed to describe and name phytoliths (Madella et al., 2005), as the preservation of phytoliths in terrestrial and aquatic paleoenvironments can be used for reconstructing past environments and human activity (Piperno, 1988; Pearsall and Piperno, 1993; Piperno and Stothert, 2003). The amount of Si accumulated in plants is species dependent and ranges from 0.1 to $10 \%$ of dry weight (Raven, 1983; Marschner, 1995; Epstein, 1999; Hodson et al., 2005; Ma and Yamaji, 2006). 
The Si uptake by plants can be active, passive or rejective. An active mechanism corresponds to a $\mathrm{Si}$ uptake in larger quantity than predicted by simple mass flow, while passive Si uptake is directly proportional to mass flow. Rejective uptake is characterized by low $\mathrm{Si}$ uptake by plants implying $\mathrm{H}_{4} \mathrm{SiO}_{4}$ accumulation in soil solution. Among the plants with an active $\mathrm{Si}$ uptake, a difference in $\mathrm{Si}$ accumulation is commonly attributed to the density of Si transporters in roots (coded by the low-silicon genes Lsil and Lsi2) and in shoots (Lsi6) (Mitani and Ma, 2005; Ma et al., 2006, 2007; Yamaji et al., 2008). For the mass-flow driven Si uptake (passive), given a same $\mathrm{Si}$ concentration in soil solution, the difference in Si accumulation between plant species could be explained by various transpiration rates (Bartoli and Souchier, 1978; Jones and Handreck, 1967; Raven, 1983; Henriet et al., 2006; Cornelis et al., 2010b).

Based on active, passive or exclusive mechanisms of $\mathrm{Si}$ uptake, plant species are classified as high-, intermediate- or non-accumulator, respectively (Takahashi et al., 1990). A classification of the plant kingdom shows that the majority of Si high-accumulators (1.0-10 wt\% shoots) belong to the monocotyledons (e.g. banana, bamboo, sugar cane, soybean, rice, wheat, barley, sorghum and oat), while most dicotyledons absorb Si passively (0.5-1.0 wt\% shoots), and some dicots such as legumes have limited Si uptake $(<0.5 \mathrm{wt} \%$ shoots) (Ma et al., 2001; Ma and Takahashi, 2002; Liang et al., 2007). Hodson et al. (2005) carried out a detailed data analysis of mean relative shoot Si concentration of 735 plant species. These data reveal that a high shoot $\mathrm{Si}$ concentration is not a general feature of monocot species and indicate that phytolith production is strongly controlled by the genetic code: the mean relative shoot Si concentration declines in the order marchantiophyta (liverworts) $>$ equisetophyta (horsetails) $>$ angiosperms $>$ gymnosperms $>$ polypdiophyta (ferns) (Table 2).

The essentiality of $\mathrm{Si}$ for terrestrial plants is still extensively debated (Takahashi et al., 1990; Richmond and Sussman, 2003). So far, only two groups of plants are known to have an absolute and quantitatively major requirement for $\mathrm{Si}$ : the diatoms and other members of the yellow-brown or golden algae, the Chrysophyceae and the Equisitaceae (Epstein, 1999). Silicon is not considered as an essential element for higher plants (Epstein, 1994; Epstein, 1999; Ma and Takahashi, 2002), but its beneficial effects on growth have been reported in a wide variety of crops, including rice, wheat, barley, and cucumber (Ma et al., 2001; Korndörfer and Lepsch, 2001; Ma and Takahashi, 2002; Ma, 2004). There is a general consensus that $\mathrm{Si}$ improves the plant resistance to various biotic and abiotic stresses. Silica deposition in leaves is a resistant structural component (Raven, 1983; Rafi et al., 1997), providing a more upright position, which favours light interception, hence promoting photosynthesis (Epstein, 1994; Marschner, 1995). Moreover, biogenic silica in plant tissues creates a hard outer layer that serves as a defense against fungal and insect attacks (Bélanger et al., 2003; Sangster et al., 2001). Finally, it is widely accepted that $\mathrm{Si}$ alleviates the toxicity of $\mathrm{Al}$ and other metal ions such as $\mathrm{Mn}$ in higher plants (Birchall, 1990; Hammond et al., 1995; Hodson and Evans, 1995; Cocker et al., 1998; Perry and Keeling-Tucker, 1998; Hodson and Sangster, 1999; Liang et al., 2001, 2007). Currently, there is no evidence of Si involved in plant metabolism (Ma et al., 2001) since no Si bearing organic compound has been identified in higher plants to date (Knight and Kinrade, 2001). The beneficial effects of Si remain reduced under optimum growth conditions, but are more obvious under stress conditions (Epstein, 1994; Bélanger et al., 1995). The Si accumulators wheat (Triticum aestivum) and rice (Oryza sativa), the premier crops for the nutrition of mankind, are susceptible to a variety of diseases if the Si supply is low (Epstein, 2001). Therefore, soils that are intensively used for cropping are fertilized on a regular basis with silicate amendments, such as wollastonite (Korndörfer and Lepsch, 2001).

\subsection{Biogenic Si preservation}

If the restitution rate of phytoliths on topsoil is higher than their dissolution rate, they may accumulate, as described on the volcanic island of La Réunion under Si-accumulating bamboos (Meunier et al., 1999). The phytolith is an adsorptive surface and is implicated in the removal of metal ions, such as $\mathrm{Al}$, from the soil solution (Epstein, 2001). These adsorptive processes tend to stabilize a part of phytoliths from dissolution (Bartoli and Wilding, 1980) and thereby reduce the amount of silicic acid returning to the biosphere through the BSi preservation in soil profile (Alexandre et al., 1997). In an equatorial rainforest, $8 \%$ of the BSi input (4$6 \mathrm{~kg} \mathrm{Si} \mathrm{ha}^{-1} \mathrm{yr}^{-1}$ ) supplies a stable pool of phytoliths with a lower turnover (Alexandre et al., 1997). In temperate deciduous and coniferous forest, the preservation of phytoliths represents 0 and $1 \mathrm{~kg} \mathrm{Si} \mathrm{ha}^{-1} \mathrm{yr}^{-1}$, respectively (Bartoli, 1983). The storage of $\mathrm{BSi}$ in grasslands ecosystem ranges from 4 to $16 \mathrm{~kg} \mathrm{Siha}^{-1} \mathrm{yr}^{-1}$ (Blecker et al., 2006). Wilding and Drees (1974) have shown that forest BSi is about 10-15 times more soluble than grass $\mathrm{BSi}$, owing to its greater specific surface area.

The amount of ASi in soils commonly ranges from $<1$ to $30 \mathrm{mg} \mathrm{g}^{-1}$ on a total soil basis (Drees et al., 1989). The highly soluble BSi pool returns to topsoil through litterfall, contributing Si to soil solution (Drees et al., 1989; Van Cappellen et al., 2003; Farmer et al., 2005; Saccone et al., 2007; Fraysse et al., 2009). A quantitative assessment of the actual amount of readily soluble $\mathrm{Si}$, whether from biogenic or pedogenic origin, in the soil can be obtained by alkaline dissolution (Sauer et al., 2006; Saccone et al., 2007; Cornelis et al., 2011).

If preserved in soil, phytoliths will be stored, dissolved and/or exported to rivers (see Fig. 1). When vegetation is highly productive and top soil erosion is significant, phytoliths may significantly contribute to the suspended load of 
Table 2. Degree of $\mathrm{Si}$ accumulation in plants estimated from mean relative shoot $\mathrm{Si}$ concentration of plant species (non-: $<0.5 \% \mathrm{Si}$, intermediate-: $0.5-1 \% \mathrm{Si}$ and high-accumulator: $>1 \% \mathrm{Si}$ ) (Ma and Takahashi, 2002), using the data analysis of Hodson et al. (2005) who adjust an average shoot $\mathrm{Si}$ concentration for each species across studies.

\begin{tabular}{|c|c|c|c|c|}
\hline Group & Species & Common name & $\begin{array}{l}\mathrm{Si}(\mathrm{wt} \%) \\
\text { in shoots }\end{array}$ & $\begin{array}{c}\text { Degree of } \mathrm{Si} \\
\text { accumulation* }\end{array}$ \\
\hline MARCHANTIOPHYTA & Marchantia polymorpha & liverworts & 5.45 & + \\
\hline \multirow[t]{2}{*}{ EQUISETOPHYTA } & Equisetum arvense & Common horsetail & 3.99 & + \\
\hline & Equisetum hyemale & Rough horsetail & 2.92 & + \\
\hline \multicolumn{5}{|l|}{ ANGIOSPERM } \\
\hline \multirow[t]{2}{*}{ Arecaceae } & Phoenix roebelenii & Date palm & 0.20 & - \\
\hline & Whashingtonia filifora & palm & 1.74 & + \\
\hline \multirow[t]{2}{*}{ Asteraceae } & Lactuca serriola & lettuce & 0.79 & \pm \\
\hline & Helianthus annuus & sunflower & 1.88 & + \\
\hline Cyperaceae & Carex cinica & sedge & 2.44 & + \\
\hline \multirow[t]{4}{*}{ Fabaceae } & Glycine $\max$ & soybean & 1.39 & + \\
\hline & Lupinus nanus & lupine & 0.28 & - \\
\hline & Phaseolus vulgaris & bean & 0.95 & \pm \\
\hline & Trifolium incarnatum & crimson clover & 0.22 & - \\
\hline \multirow[t]{2}{*}{ Fagaceae } & Quercus robur & pedunculate oak & 1.54 & + \\
\hline & Fagus sylvatica & European beech & 6.08 & \pm \\
\hline \multirow[t]{2}{*}{ Lamiaceae } & Mentha longifolia & $\operatorname{mint}$ & 0.73 & \pm \\
\hline & Mentha piperita & peppermint & 1.22 & + \\
\hline Liliaceae & Allium fistulosum & onion & 0.31 & - \\
\hline Musaceae & Musa basjoo & banana & 0.98 & \pm \\
\hline \multirow[t]{9}{*}{ Poaceae } & Arundinaria gigantea & cane & 8.77 & + \\
\hline & Avena sativa & oat & 1.51 & + \\
\hline & Hordeum vulgare & barley & 1.82 & + \\
\hline & Oryza sativa & rice & 4.17 & + \\
\hline & Saccharum officianum & sugarcane & 1.51 & + \\
\hline & Secale cercale & rye & 1.26 & + \\
\hline & Sorghum bicolor & sorghum & 1.54 & + \\
\hline & Triticum aestivum & wheat & 2.45 & + \\
\hline & Zea mays & maize & 0.83 & \pm \\
\hline Urticacea & Urtica dioica & nettle & 1.34 & + \\
\hline \multicolumn{5}{|l|}{ GYMNOSPERM } \\
\hline \multirow[t]{6}{*}{ Pinaceae } & Abies alba & European silver fir & 0.34 & - \\
\hline & Larix decidua & European larch & 0.87 & \pm \\
\hline & Picea abies & Norway spruce & 1.36 & + \\
\hline & Picea rubens & Red spruce & 0.32 & - \\
\hline & Pinus strobus & White pine & 0.12 & - \\
\hline & Pseudotsuga menziesii & Douglas fir & 0.32 & - \\
\hline \multicolumn{5}{|l|}{ POLYPODIOPHYTA } \\
\hline Dryopteridaceae & Dryopteris carthusiana & Narrow-buckler fern & 0.18 & - \\
\hline Polypodiaceae & Polypodium vulgare & Rockcap fern & 0.15 & - \\
\hline
\end{tabular}

${ }^{*},-, \pm$ and + : Si non-, intermediate- and high-accumulator. 
rivers. In the Nyong basin (Cameroon), phytoliths originating from the soil erosion contribute to more than $90 \%$ of the BSi pool in Nyong River suspended load, and account for $4 \%$ of the total suspended load (Cary et al., 2005).

\subsection{Atmospheric Si input}

The Si atmospheric dust inputs in the biogeosphere must be taken into account in biogeochemical studies. In highly weathered soils, Chadwick et al. (1999) show that atmospheric inputs alone (marine aerosols and dusts) can sustain the productivity of Hawaiian rainforest.

In addition to the DSi transfer by rivers, the eolian erosion of the land surface is a potentially important transport of $\mathrm{Si}$ to the oceans. Airborne particles enter the surface ocean $\left(0.28 \times 10^{12} \mathrm{~kg} \mathrm{Si} \mathrm{yr}^{-1}\right)$ where a small fraction dissolves $\left(0.01 \times 10^{12} \mathrm{~kg} \mathrm{Si} \mathrm{yr}^{-1}\right)$ (Tréguer et al., 1995) (Fig. 1). Depending on its mineralogy, the impact of dust on soil genesis and on terrestrial biogeochemical cycle of $\mathrm{Si}$ varies greatly by region (Simonson, 1995). Street-Perrott and Barker (2008) show that atmospheric Si input in temperate and tropical forests ranges from 0.04 to $2 \mathrm{~kg} \mathrm{Si} \mathrm{ha}^{-1}$ year $^{-1}$. Dry Si deposition is highest near the sources of the African, Arabian, Asian and Australian deserts (Tegen et al., 2002). In East African, savanna fires would be a significant source of atmospheric phytolith particles (Street-Perrott and Barker, 2008). In most intensely weathered soils, wind-blown dust becomes the dominant source of Si on topsoil: near-surface horizons of Hawaiian soils contain as much as $30 \%$ quartz, a mineral absent from local parent material (Kurtz et al., 2001). In soil derived from basaltic ash (Cameroon), the content of quartz from Saharan dust deposition on topsoil ranges from 2-8\%, depending on soil localization (Opfergelt et al., 2010). In Northeast Sweden, the Si content in tree leaves originates both from Si plant uptake and from local airborne particulate material, quantifying this exogenous $\mathrm{Si}$ contribution between 1 and $70 \%$ (Engström et al., 2008).

Wet precipitation can also sustain $\mathrm{Si}$ to the soil-plant system, such as in a rice field in Camargue (France) where the annual precipitation flux give a DSi input of $3 \pm$ $2 \mathrm{~kg} \mathrm{Si} \mathrm{ha}^{-1} \mathrm{yr}^{-1}$ (Desplanques et al., 2006). Similarly, in two Amazonian forest sides in Brazil, Si inputs on topsoil from the rain and from dust were small but not negligible: $0.6 \mathrm{~kg} \mathrm{Si} \mathrm{ha}^{-1} \mathrm{yr}^{-1}$ (Cornu et al., 1998). Finally, in humid climates, most values of annual $\mathrm{Si}$ inputs through rainfall are $<1.4 \mathrm{~kg} \mathrm{Si} \mathrm{ha}^{-1} \mathrm{yr}^{-1}$ (Sommer et al., 2006). More generally, atmospheric inputs were estimated at $<1,1.5$ and $2 \mathrm{~kg} \mathrm{Si} \mathrm{ha}^{-1} \mathrm{yr}^{-1}$ (Alexandre et al., 1997; Bartoli, 1983; Blecker et al., 2006, respectively). In a forested Japanese catchment, increasing atmospheric Si deposition from dust storm events does not noticeably impact short-term stream water fluxes (Hartmann et al., 2008). The atmospheric Si supply in biogeosphere is thus ubiquitous but very low compared to other $\mathrm{Si}$ inputs in the soil-plant system (StreetPerrott and Barker, 2008).

\section{Transfer of dissolved Si from soil-plant systems towards rivers}

\subsection{Si in soil-plant systems}

Terrestrial plants and their associated microbiota directly affect silicate mineral weathering in several ways: (i) affecting the temperature of the soil, (ii) protecting soil against erosion, (iii) generating of chelating ligands, (iv) modifying $\mathrm{pH}$ through production of $\mathrm{CO}_{2}$ and organic acids (mainly when $\mathrm{pH}$ is below 4-5), (v) modifying element concentrations in soil solution by root uptake and return by litter and (vi) altering the physical properties of a soil, particularly the exposed surface areas of minerals and the residence time of water (Drever, 1994; Moulton et al., 2000).

Silicon accumulation process by vegetation can be important. For instance, a Si-accumulator forest $(1.1 \% \mathrm{Si}$ in leaves) with a biomass production of 16 tons dry weight $\mathrm{yr}^{-1}$ would extract about $200 \mathrm{~kg} \mathrm{Si} \mathrm{ha}^{-1} \mathrm{yr}^{-1}$ (Lovering, 1959). Following the conversion of silicates into silicic acid, terrestrial higher plants convert silicic acid into biogenic silica (Raven, 1983, 2001). It is well known that a part of the DSi released by mineral weathering is cycled through vegetation at the surface of the earth (Conley, 2002) before its transfer to oceans (Bartoli, 1983; Lucas et al., 1993; Alexandre et al., 1997; Markewitz and Richter, 1998; Conley, 2002; Derry et al., 2005; Fulweiler and Nixon, 2005; Blecker et al., 2006; Sommer et al., 2006; Gérard et al., 2008; Cornelis et al., 2010c).

It is well known that aquatic macrophytes and wetland species can contain significant amounts of Si (Struyf and Conley, 2009; Struyf et al., 2009). In a reed-dominated small freshwater tidal marsh and given the high solubility of biogenic silica, more than $40 \%$ of DSi export can be attributed to reed decomposition (Struyf et al., 2007). Moreover, the transport of Si through boreal watersheds could be impacted by silica storage originating from diatoms accumulation in peat layers (Kokfelt et al., 2009, 2010).

In temperate forest ecosystem, the $\mathrm{Si}$ uptake depends on tree species and soil type, ranging from 2 to $44 \mathrm{~kg} \mathrm{Si} \mathrm{ha}^{-1} \mathrm{yr}^{-1}$ (Bartoli, 1983; Markewitz and Richter, 1998; Fulweiler and Nixon, 2005; Gérard et al., 2008; Cornelis et al., 2010c). In humid tropical conditions, the Si recycling by forest trees is evaluated to up to $67 \mathrm{~kg} \mathrm{ha}^{-1} \mathrm{yr}^{-1}$ (Congo rainforest; Alexandre et al., 1997), an extremely high value (970-1380 $\mathrm{kg} \mathrm{ha}^{-1} \mathrm{yr}^{-1}$ ) was obtained in the particular case of a bamboo forest (Meunier et al., 1999). Dry and humid temperate grasslands display a Si uptake between 22 and $59 \mathrm{~kg} \mathrm{ha}^{-1} \mathrm{yr}^{-1}$ (Blecker et al., 2006). The active uptake by vegetation decreases $\mathrm{H}_{4} \mathrm{SiO}_{4}$ concentration in soil solution, and thus accelerates the mineral weathering rate (see Eq. 3) (Exley, 1998). Indeed, Si-accumulating plants are able to accelerate the dissolution of basalt (Hinsinger et al., 2001).

The Si recycling by vegetation (forest, grassland and wetlands) strongly controls the amount of Si restituted on 
Table 3. Si fluxes (uptake, restitution and drainage) in forest and grassland ecosystems.

\begin{tabular}{lllll}
\hline & \multicolumn{3}{c}{$\mathrm{Si}\left(\mathrm{kg} \mathrm{ha}^{-1} \mathrm{yr}^{-1}\right)$} \\
\cline { 2 - 5 } & $\begin{array}{l}\text { Vegetation } \\
\text { uptake }\end{array}$ & $\begin{array}{l}\text { Restitution } \\
\text { by litterfall }\end{array}$ & $\begin{array}{l}\text { Export } \\
\text { by drainage }\end{array}$ & Reference \\
\hline Equatorial forest (Ferralsols) & & 41 & 11 & 1 \\
Equatorial forest (Ferralsols) & $58-76$ & $58-76$ & 16 & 2 \\
Temperate deciduous forest (Cambisols) & 23 & 22 & 3 & 3 \\
Temperate deciduous forest (Cambisols) & $18-23$ & $18-19$ & $6-7$ & 4 \\
Temperate coniferous forest (Cambisols) & $30-43$ & $29-42$ & $0.7-1$ & 4 \\
Temperate coniferous forest (Cambisols) & 44 & 36 & 5 & 6 \\
Temperate pine forest (Cambisols) & 2.3 & 2.1 & 9.4 & 4 \\
Temperate pine forest (Podzols) & 6 & 5 & 28 & 3 \\
Temperate pine forest & 16 & 14 & 17 & 5 \\
Dry grasslands (Aridisols) & - & 26 & 0.2 & 7 \\
Humid grasslands (Mollisols & & 59 & 11 & 7 \\
\hline
\end{tabular}

1. Lucas et al. (1993); 2. Alexandre et al. (1997); 3. Bartoli (1983); 4. Cornelis et al. (2010c); 5. Markewitz and Richter (1998); 6. Gérard et al. (2008); 7. Blecker et al. (2006)

topsoil, litterfall being the most important Si flux from vegetation to soil (Sommer et al., 2006; Blecker et al., 2006; Struyf and Conley, 2009; Cornelis et al., 2010c; Struyf et al., 2010). Silicon recycling by vegetation seems to be of the same order of magnitude as DSi outputs from soils (Table 3). More specifically, the Si uptake by forest vegetation is negatively correlated with the amount of DSi leached out from the soil profile (Cornelis et al., 2010c). In 2005, the total forest area worldwide was estimated to be 3952 million hectares, which corresponds to about $30 \%$ of the land area (FAO, 2006). Assuming a mean Si uptake by global forest vegetation of $40 \mathrm{~kg} \mathrm{Si} \mathrm{ha}^{-1} \mathrm{yr}^{-1}$ (Table 3), the annual forest BSi production would be $0.15 \times 10^{12} \mathrm{~kg} \mathrm{Si} \mathrm{yr}^{-1}$, which represents $6.3 \%$ of the amount of the total terrestrial Si biologically fixed as BSi $\left(2.5 \times 10^{12} \mathrm{~kg} \mathrm{Si} \mathrm{yr}^{-1}\right)$ (Laruelle et al., 2009). In addition, considering a mean $\mathrm{Si}$ output from forested land of $10 \mathrm{~kg} \mathrm{Si} \mathrm{ha}^{-1} \mathrm{yr}^{-1}$ (Table 3), the global DSi leached out from forest ecosystem would be $0.04 \times 10^{12} \mathrm{~kg} \mathrm{Si} \mathrm{yr}^{-1}$, which represents $27 \%$ of the net DSi inputs from continents to oceans.

The DSi load to rivers is significantly reduced when significant amounts of BSi accumulate in vegetation. Indeed, the $\mathrm{Si}$ uptake by terrestrial ecosystems thus significantly increases the chemical weathering rate without necessarily increasing the measured denudation rate (Alexandre et al., 1997; Street-Perrott and Barker, 2008; Cornelis et al., 2010c). This observation is confirmed by the significant increase in the transport of DSi by rivers with deforestation (Saccone et al., 2008; Conley et al., 2008). Conley et al. (2008) showed the effect of deforestation in a temperate forest ecosystem where an increase in DSi output to the hydrosphere was caused by dissolution of the amorphous BSi, which was restituted on topsoil.

As shown in Fig. 1, the global agricultural Si export is estimated to be $0.22 \times 10^{12} \mathrm{~kg} \mathrm{Si} \mathrm{yr}^{-1}$ (Matichenkov and
Bocharnikova, 2001), which is of the order of magnitude as the total dissolved Si transferred from continents to oceans by rivers $\left(0.14 \times 10^{12} \mathrm{~kg} \mathrm{Si} \mathrm{yr}^{-1}\right)$ (Tréguer et al., 1995). When $\mathrm{Si}$ accumulators such as rice and wheat are cultivated, their biomass exported from the field represents a net loss of Si from the soil-plant system (Meunier et al., 2008). As a consequence, intensive cropping of $\mathrm{Si}$-accumulating plants (rice and sugar cane), is responsible for a significant decrease of $\mathrm{Si}$ in soils within a few decades (Meunier, 2003).

The large Si biocycling by terrestrial vegetation highlights the necessity to incorporate the part of $\mathrm{H}_{4} \mathrm{SiO}_{4}$ polymerized in higher plants and in phytoplankton as BSi (Bormann et al., 1998; Meunier, 2003; Street-Perrott and Barker, 2008) in studies using DSi concentrations in rivers to understand chemical weathering rates and solute generation processes (Gaillardet et al., 1997, 1999a, b; Oliva et al., 1999; Vuai and Tokuyama, 2007). Indeed, the mass-balance of $\mathrm{Si}$ at the watershed scale has to be evaluated taking into account the pathways of Si between lithosphere and biosphere (recycling, immobilization, exportation and restitution of Si by vegetation) before its transfer to rivers. Moreover, most watershed studies, which have estimated soil weathering rates, assume that surface discharge chemistry reflects the soil water chemistry. However significant discrepancies between soil and surface chemistries are apparent in some cases and could be explained by rapid surface runoff (DSi in surface discharge $<$ DSi in soil water) and weathering at a narrow interface between the bedrock and soil zone in saprolite (DSi in surface discharge $>$ DSi in soil water) (White, 1995). Finally, before its transfer to oceans, the dissolved and particulate load can be deposited and DSi can be extracted by grasses and stored in phytoliths (Wüst and Bustin, 2003; Ding et al., 2004), taken up by sponges and stored in spicules (Chauvel et al., 1996) or taken up by phytoplankton and stored in diatom 
Table 4. The DSi concentration of freshwater at the global scale (modified from Exley, 1998).

\begin{tabular}{lc}
\hline & DSi $\left(\mu \mathrm{mol} 1^{-1}\right)$ \\
\hline Australia & 65 \\
Europe & 126 \\
North America & 151 \\
Asia & 196 \\
South America & 200 \\
Africa & 389 \\
Global average* & 150 \\
\hline
\end{tabular}

* Estimation of discharge-weighted average silicic acid concentration in rivers (Tréguer et al., 1995).

frustules (Ragueneau et al., 2006). Struyf et al. (2009) confirm that wetlands, as a biological Si sink, control the fluxes of both DSi and ASi along the land-ocean continuum boundary.

\subsection{Dissolved Si transfer}

The average DSi concentration in freshwater at the global scale displays huge variations depending on the geographical region (Table 4; Exley, 1998). The low DSi concentration of Australian freshwater reflects the heavily weathered soils in this region. In boreal and arctic rivers, the concentration of DSi, 30-50\% lower than the global average, seems to be mainly controlled by the soil and vegetation through the production of organic acids, as shown by a positive correlation between total organic carbon and DSi in these rivers (Humborg et al., 2006b).

However, the DSi concentration alone does not provide clues on the sources and processes affecting riverine fluxes of DSi. In weathering-limited systems, transport processes may remove products of weathering faster than the neoformation and precipitation of secondary phases. In contrast, in transport-limited systems, river load depends on the availability of water as a transporting agent (Drever, 1988; Gaillardet et al., 1995). This will induce variations in DSi transfer towards rivers between geographical regions. Because mineral weathering (temperature and physical denudation) and transport conditions (runoff) exert a major control on processes governing the DSi inputs to rivers (Meybeck, 1979; Anderson et al., 1997; Gaillardet et al., 1999a; Turner et al., 2003; Fulweiler and Nixon, 2005; Jennerjahn et al., 2006; Georg et al., 2006; Gislason et al., 2009) and differ geographically, DSi fluxes will be discussed separately in tropical and non-tropical rivers following various geographical regions (Jennerjahn et al., 2006; Table 5).

Currently, the average global DSi flux is two to three times higher in tropical than in non-tropical rivers (Tréguer et al., 1995): $74 \%$ of the total annual DSi input by rivers into the oceans originates from tropical regions $(0.12 \times$
Table 5. Average DSi flux and load per continent and per latitude (tropical or not) towards large rivers. Data are from Jennerjahn et al. (2006).

\begin{tabular}{lrr}
\hline & $\begin{array}{c}\text { DSi flux } \\
\text { DSi load }\end{array}$ & \\
\hline Tropical rivers & $\left(\mathrm{kg} \mathrm{Si} \mathrm{ha}^{-1} \mathrm{yr}^{-1}\right)$ & $\left(10^{9} \mathrm{~kg} \mathrm{Si} \mathrm{yr}^{-1}\right)$ \\
\hline Africa & & 8.9 \\
South America & 21.9 & 24.3 \\
Asia & 23.6 & 11.5 \\
Oceania & 95.1 & 1.4 \\
\hline Non-tropical rivers & & \\
\hline Oceania & 0.2 & 0.2 \\
Africa & 0.6 & 0.3 \\
North America & 7.5 & 5.4 \\
Asia & 7.9 & 12.9 \\
Europe & 7.9 & 1.6 \\
South America & 32.0 & 6.6 \\
\hline Total Load & & $74.5^{*}$ \\
\hline
\end{tabular}

* This estimation of DSi load from rivers into oceans represents $50 \%$ of the total riverine DSi load calculated by Tréguer et al. (1995) (see Fig. 1) since this table only represents half of the world river discharge $\left(37400 \mathrm{~km}^{3} \mathrm{yr}^{-1}\right)$ (Tréguer et al., 1995).

$\left.10^{12} \mathrm{~kg} \mathrm{Si} \mathrm{yr}^{-1}\right)$ and $20 \%$ from temperate regions $(0.03 \times$ $\left.10^{12} \mathrm{~kg} \mathrm{Si} \mathrm{yr}^{-1}\right)$. This distribution could vary as precipitation patterns change with an increase in most of the Northern hemisphere $(0.5-1 \% /$ decade) and decrease in sub-tropical land areas (0.3\%/decade) (Lal, 2004).

Tropical ecosystems represent $33 \%$ of the land mass (Meunier et al., 2001) and contribute the major part of the DSi transfer from continents to the oceans. Indeed, the river basins with the largest fluxes of total $\mathrm{CO}_{2}$ consumption are all located in the humid tropics (Gaillardet et al., 1999b). Tropical rivers in Asia and Oceania display high DSi fluxes that match the optimum weathering and transport conditions (Jennerjhan et al., 2006; Beusen et al., 2009). The DSi yield in the Japanese Archipelago, a hyperactive region, is 6.6 times higher than the world average (Hartmann et al., 2010). These volcanic "hot spots" environments are characterized by a young geology, an active tectonic region of the circum-Pacific ring of fire, a high runoff and a high silicate weathering rate (Milliman and Meade, 1983; Milliman and Syvitski, 1992; Sommer et al., 2006). Basic igneous rocks show the highest DSi yields with respect to a given runoff while the least DSi per runoff is mobilized from acidic plutonic rocks (Jansen et al., 2010; Hartmann et al., 2010). The model predictions of Beusen et al. (2009) give a strong indication that DSi fluxes depend on the precipitation and the occurrence of volcanic rocks. Despite its restricted spatial distribution, basalts are eight times more soluble than granites (Dupré et al., 2003), and contain a high proportion of ferromagnesian minerals susceptible to chemical weathering by 
higher plants (Cochran and Berner, 1996). Slope constitutes another important controlling factor on DSi fluxes besides lithology and runoff (Hartmann et al., 2010).

Non-tropical rivers generally display much lower relative silicate weathering rates and DSi fluxes (Jennerjahn et al., 2006). Especially the Siberian and Canadian rivers contribute to $\sim 10 \%$ to the total DSi input into oceans (Gordeev et al., 1996). With low temperature and runoff in weatheringlimited temperate regions, DSi fluxes should be driven by soil and vegetation (Humborg et al., 2006b) through (i) the high supply of organic protons lowering $\mathrm{pH}$ in topsoils (ii) the high Si recycling rates by vegetation compared to DSi fluxes in rivers (Table 3 ), and (iii) the production of reactive phytoliths on topsoil, the two former phenomena being likely to accelerate the mineral weathering rates. In a granitic forested ecosystem, the river DSi concentrations exhibit a strong seasonal signal that did not vary in a regular way with water discharge or water temperature (Fulweiler and Nixon, 2005). In this study, the spring decline in river DSi concentration could be due to Si uptake by terrestrial vegetation (Fulweiler and Nixon, 2005; Engström et al., 2010). According to the low DSi fluxes and loads in non-tropical rivers, we could conclude that the biological processes are insufficient to counterbalance the lower weathering rates with regard to transferring DSi from continents to oceans.

The soil-vegetation system type may also impact the DSi fluxes in weathering-limited tropical watersheds (Sommer et al., 2006) since the DSi flux in poorly developed soils under subarctic climate (Anderson et al., 1997, 2000) is of the same order of magnitude as that of strongly developed soils of tropical climate (Oliva et al., 1999).

The relatively high DSi flux from non-tropical South America (Beusen et al., 2009) could be explained by the physical denudation in mountainous areas combined with high runoff and temperature which provide ideal conditions for high chemical weathering rates and high DSi transport (Milliman and Syvitski, 1992; Gaillardet et al., 1999a; Georg et al., 2006). Indeed, physical weathering and erosion in areas of high relief enhance weathering by continually exposing fresh mineral surfaces (Summerfield and Hulton, 1994; Street-Perrott and Barker, 2008). However, physical weathering in high-latitude watersheds seems to lead mostly to the formation of clay minerals, but does not immediately lead to higher DSi fluxes as observed for tropical regions with active tectonics (Anderson et al., 2000; Humborg et al., 2006b). Furthermore, a recent study shows that land use is the most important controlling factor of total biologically reactive silica fluxes in a temperate European river basin (Struyf et al., 2010).

In summary, a hierarchy of driving variables that control Si fluxes from the continents to the oceans can be identified. At the global scale, runoff is the main driver of DSi fluxes, followed by temperature. At regional scale, DSi fluxes are a function of (1) the catchment lithology (content of weatherable minerals), (2) the geomorphology, (3) the hydrologi- cal conditions (discharge), (4) the soil development in the catchment, and (5) the biological processes (Sommer et al., 2006; Beusen et al., 2009; Hartmann et al., 2010). Although the drivers of DSi fluxes from land to oceans are identified, the relative contribution of the two different solid Si pools (litho/pedogenic and biogenic) to the release of DSi in aqueous phase is still poorly constrained.

\section{Tracing biogeochemical Si cycle in the soil-plant system}

Since $\mathrm{Si}$ is a ubiquitous element in the biogeosphere, tracing the origin of the DSi output from a soil-plant system requires the use of (1) a Si mass-balance (Bartoli, 1983; Lucas et al., 1993; Alexandre et al., 1997; Farmer et al., 2005; Gérard et al., 2008; Cornelis et al., 2010c) and (2) geochemical tracers. Two tracers of the Si cycle in weathering environments have been identified so far: Ge/Si ratios (Derry et al., 2005; Lugolobi et al., 2010) and stable Si isotopes (Ding et al., 2004; Ziegler et al., 2005a; Georg et al., 2006, 2007, 2009a; Bern et al., 2010; Cardinal et al., 2010; Cornelis et al., 2010a; Engström et al., 2010; Opfergelt et al., 2010).

Through the calculation of Si uptake, Si restitution, $\mathrm{Si}$ drainage (Table 3), atmospheric Si inputs and phytolith preservation in soils, a Si mass-balance in specific ecosystems allows an estimation of the Si release by silicate weathering and by phytolith dissolution, respectively. However, these approximations ignore other important $\mathrm{Si}$ sinks in the soil-plant system such as HAS and short-range ordered aluminosilicates formation, neoformation of secondary clay minerals, opaline spheres precipitation and $\mathrm{Si}$ adsorption onto $\mathrm{Fe}$ and $\mathrm{Al}$ (hydr)oxides. Thus, we recommend that $\mathrm{Si}$ mass balances should be determined and a detailed physicochemical characterization of the soil-plant system should be performed when using geochemical tracers $(\mathrm{Ge} / \mathrm{Si}$ ratios and $\delta^{30} \mathrm{Si}$ ) to obtain insight in the sources and fate of $\mathrm{Si}$ in these biogeochemical systems.

Germanium $(\mathrm{Ge})$ is a trace element with very similar geochemical properties when compared to Si because it substitutes for $\mathrm{Si}$ in aluminosilicates mineral lattices. Studying $\mathrm{Ge} / \mathrm{Si}$ fractionation allows for tracing the weathering of $\mathrm{Si}$ containing phases and the dynamics of DSi produced in soilplant systems (Kurtz et al., 2002; Derry et al., 2005; Scribner et al., 2006). Secondary clay minerals and biogenic opal display contrasting $\mathrm{Ge} / \mathrm{Si}$ ratios since clay-sized weathering products are enriched in Ge (Murnane and Stallard, 1990; Kurtz et al., 2002; Kurtz and Derry, 2004; Delvigne et al., 2009; Opfergelt et al., 2010; Lugolobi et al., 2010; Cornelis et al., 2010a) and biogenic silica (BSi) polymerized in plants as phytoliths is depleted in Ge (Derry et al., 2005; Blecker et al., 2007; Delvigne et al., 2009; Cornelis et al., 2010a; Lugolobi et al., 2010). The current interpretation of $\mathrm{Ge} / \mathrm{Si}$ ratios of soil solutions relies on the relative importance of a low-Ge end member derived from incongruent dissolution 
of fresh rock minerals and biomineralization and a high-Ge end member produced by congruent dissolution of pedogenic minerals (Kurtz et al., 2002).

The fractionation of stable $\mathrm{Si}$ isotopes also holds a great potential to assess the relative contribution of $\mathrm{Si}$ released from litho/pedogenic and biogenic Si pools in the soil solution (Ziegler et al., 2005a; Engström et al., 2008; Georg et al., 2009b; Cornelis et al., 2010a). The Si isotope composition of a sample is expressed as $\delta^{30} \mathrm{Si}$ defined as follows:

$\delta^{30} \mathrm{Si}=\left[\frac{\left(\frac{{ }^{30} \mathrm{Si}}{{ }^{28} \mathrm{Si}}\right)_{\text {sample }}}{\left(\frac{{ }^{30} \mathrm{Si}}{{ }^{28} \mathrm{Si}}\right)_{\mathrm{NBS}-28}}-1\right] \cdot 1000$

Measured $\delta^{30} \mathrm{Si}$ values are expressed in $\%$ o with respect to the NBS-28 standard. The neoformation of secondary precipitates such as clay minerals (Ziegler et al., 2005a, b; Opfergelt et al., 2008, 2010; Bern et al., 2010; Cornelis et al., 2010a), the plant Si uptake producing biogenic opal (Douthitt, 1982; Ziegler et al., 2005a; Ding et al., 2005; Opfergelt et al., 2006a, b; Ding et al., 2008; Opfergelt et al., 2008), and the adsorption of Si onto Fe-oxides (Delstanche et al., 2009; Opfergelt et al., 2009) are three processes favouring the incorporation of light $\mathrm{Si}$ isotopes, contributing to enrich rivers in heavy $\mathrm{Si}$ isotopes (De La Rocha et al., 2000; Ding et al., 2004; Georg et al., 2006, 2007; Cardinal et al., 2010). Natural environments impacted simultaneously by all these processes will display a bulk $\mathrm{Si}$ isotopic signature of $\mathrm{DSi}$. Understanding the contribution of those three processes on DSi output can hardly be done with $\delta^{30} \mathrm{Si}$ systematics alone. Comparing $\mathrm{Ge} / \mathrm{Si}$ ratios with $\mathrm{Si}$ isotope data (Delvigne et al., 2009; Opfergelt et al., 2010; Lugolobi et al., 2010; Cornelis et al., 2010a) may provide a better understanding of the origin of DSi exported from various soil-plant systems towards rivers.

The interpretation of $\mathrm{Ge} / \mathrm{Si}$ ratios and $\delta^{30} \mathrm{Si}$ signatures in waters exported from the soil-plant system should thus combine a detailed characterization of (i) the processes involved, (ii) the seasonal variation of these processes, and (iii) the mineralogy of secondary weathering products. The seasonal variation should help to isolate biological uptake, but also include alternating dry and rainy seasons impacting drainage, modifying $\mathrm{Si}$ available for secondary precipitates and $\mathrm{Si}$ export from soil solutions to rivers. The timescale of processes also needs to be considered, as biological uptake and $\mathrm{Si}$ adsorption occurred at a very short timescale (day to season) compared to clay mineral formation (year to geological timescale). This should help to identify the dominant process depending on seasonal variations, considering that some processes can also be neglected based on the mineralogy.
By comparing different combinations of processes interacting in the soil-plant system, we can infer how ${ }^{30} \mathrm{Si}$ and $\mathrm{Ge} / \mathrm{Si}$ ratios can be useful to evaluate the impact of Si recycling through vegetation on DSi exported. Plant Si uptake, polymerization and return in phytoliths to the soil induce a BSi pool enriched in light isotopes (lower $\delta^{30} \mathrm{Si}$ ) and depleted in $\mathrm{Ge}$ (lower $\mathrm{Ge} / \mathrm{Si}$ ) relative to the initial $\mathrm{Si}$ signature. A stable pool of phytoliths can be preserved in soils, therefore producing soil water relatively enriched in heavy $\mathrm{Si}$ isotopes, but depleted in Ge if plant roots are not decomposed since Ge can be organically trapped in roots (Delvigne et al., 2009). Dissolution of the labile pool of phytoliths will impact soil water signature by decreasing $\delta^{30} \mathrm{Si}$ values and $\mathrm{Ge} / \mathrm{Si}$ ratios.

In addition to the impact of vegetation, the geochemical signature of DSi output from the soil-plant system can also be affected by abiotic processes, including light $\mathrm{Si}$ isotopes sequestration by clay minerals and adsorption onto Fe-oxides and Ge sequestration into secondary clay minerals. Assuming no dissolution of these secondary precipitates, DSi in soil solution exported will evolve towards isotopically heavier and $\mathrm{Ge}$ depleted relative to the parent material. However in organic rich environments, dissolution of secondary minerals occurs and releases light $\mathrm{Si}$ isotopes and Ge inducing lower $\delta^{30} \mathrm{Si}$ values and higher $\mathrm{Ge} / \mathrm{Si}$ ratios (Cardinal et al., 2010; Cornelis et al., 2010a). Given the contrasted variation of $\mathrm{Ge} / \mathrm{Si}$ and $\mathrm{Si}$-isotopic ratios, both tracers are useful to evaluate the origin of DSi in some specific environments. However, those tracers are not designed to calculate net $\mathrm{Si}$ fluxes exported from the soil-plant system.

\section{The origin of the dissolved Si output from various soil-plant systems}

The origin of the dissolved Si output from various soil-plant systems towards rivers will be assessed through two controlling factors: (i) the weathering ability of the system, and (ii) the impact of vegetation on weathering products (Fig. 3). The sources of DSi fluxes including litho/pedogenic Si components and/or biogenic Si components can thus be classified more systematically. In this classification, it is assumed that some young tropical soils still have significant amounts of weatherable minerals available (Scenario 1; Fig. 3a). For Scenario 2 we assume that many tropical systems have old and highly weathered soils, in which the reservoir of primary minerals is exhausted (Scenario 2; Fig. 3b). In non-tropical regions, the climate is relatively less favorable to silicate weathering while the stock of mineral-derived $\mathrm{Si}$ is usually higher than in tropical environments (Scenario 3; Fig. 3c), except for arid climates (Scenario 4; Fig. 3d) where the environmental conditions do not favour silicate weathering, and where no Si soil-plant cycling takes place. The variations of biogeochemical Si signatures ( $\mathrm{Ge} / \mathrm{Si}$ ratios and $\delta^{30} \mathrm{Si}$ ) in those contrasted environments are discussed. 
(a) Weathering unlimited scenario (optimal climate and soil conditions)

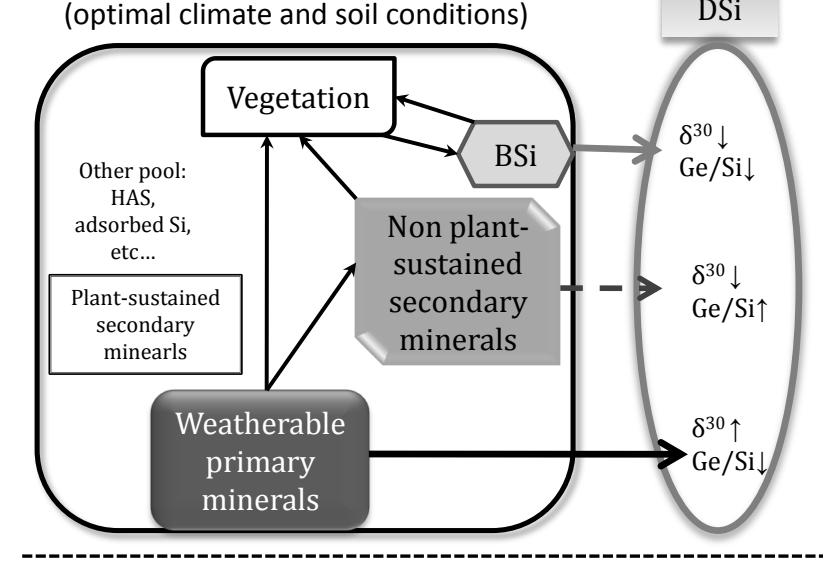

(c) Climate weathering-limited scenario
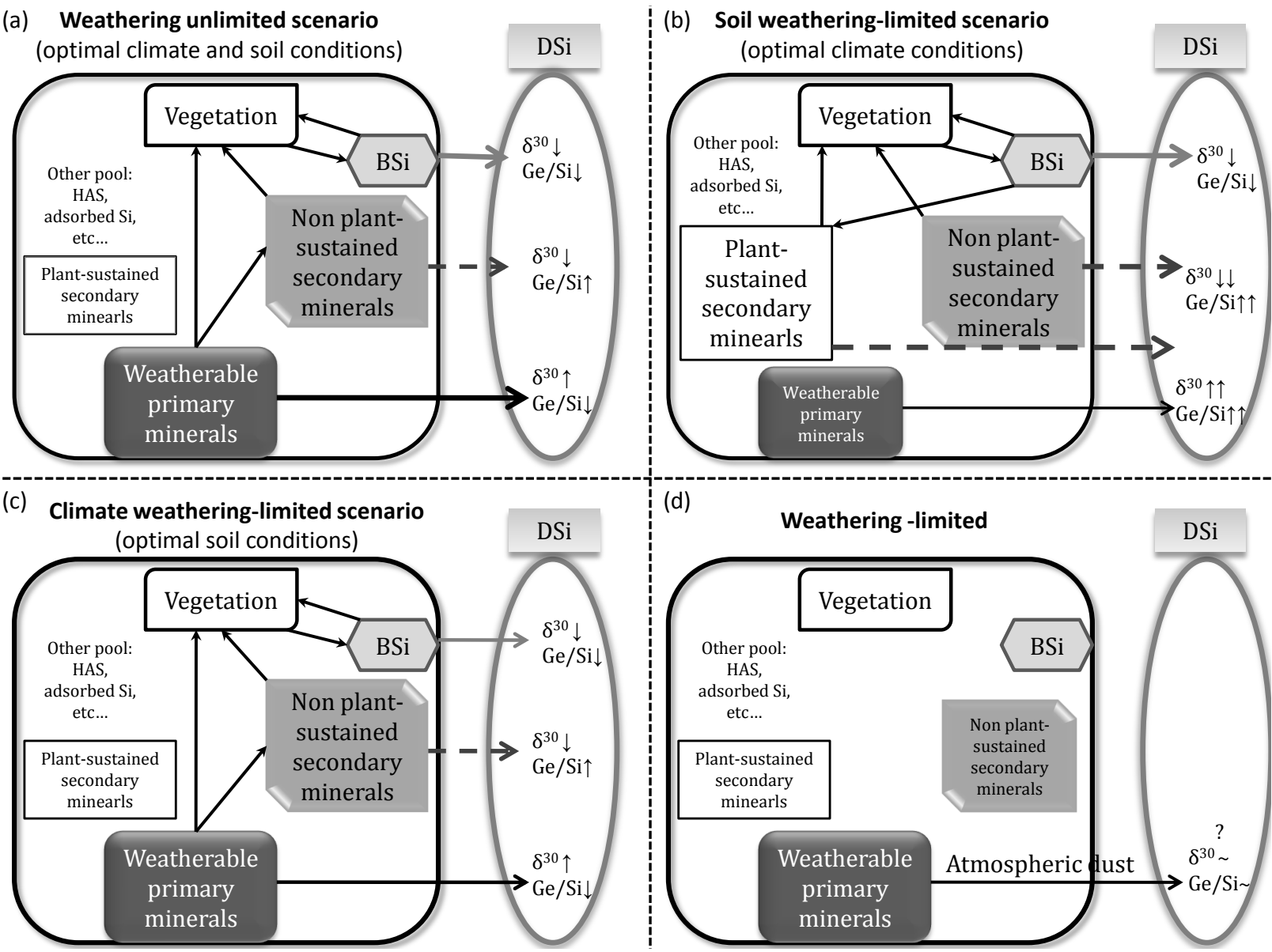

Fig. 3. Schematic representation of the weathering ability of a soil-plant system as a function of the climate (runoff and temperature), soil conditions (presence of weatherable minerals) and recycling by vegetation. The scenarios are described in the text: (a) weathering unlimited (scenario 1); (b) soil weathering-limited (scenario 2); (c) climate weathering-limited (scenario 3); (d) weathering-limited scenario. The arrows represent the dissolution of the various $\mathrm{Si}$ pools and its impact on the DSi geochemical $\left(\delta^{30} \mathrm{Si}, \mathrm{Ge} / \mathrm{Si}\right)$ signatures relative to parental material. The black arrow from the weatherable mineral pool means a DSi signature resulting from weathering of primary minerals assuming secondary precipitate formation and stability. The sizes of the arrows represent relative DSi fluxes.

These four scenarios are like "end members"described to understand the processes. Natural conditions are not as simplified as in these scenarios, since the environmental conditions can oscillate between these scenarios; e.g., a soil chronosequence is characterized by a decrease of weatherable mineral content with the age of soils in identical climatic conditions; a soil climosequence is characterized by identical weatherable mineral content in different climatic conditions (temperature and runoff). Thus, the DSi signature of a local soil-plant ecosystem can be influenced by a mix of two scenarios ( 1 and 2 or 1 and 3, for a chronosequence and a climosequence respectively). The biogeochemical tracers are therefore very useful to understand the transfer of elements in environments that are well-defined and characterized.

\subsection{Scenario 1: weathering-unlimited}

In a system with unlimited weathering ability, the release of DSi from land mass to oceans is largely driven by climatic conditions such as temperature and runoff promoting silicate weathering and transport (Gaillardet et al., 1999a; Jennerjahn et al., 2006). However, the relative contribution of weathering and BSi cycling in weathering-unlimited systems is still poorly quantified.

Two recent studies demonstrate the impact of BSi recycling and restitution in topsoil on the mobility of DSi from continents to rivers. The Luquillo stream from a granitic mountain range characterized by the fastest measured rates of granitoid weathering (Puerto Rico) is dominated by Si derived from incongruent mineral weathering at the bedrocksaprolite interface as revealed by the positive ${ }^{30} \mathrm{Si}$ values of soil solution (Ziegler et al., 2005b). However, the ${ }^{30} \mathrm{Si}$ 
signature $(-1.5 \%$ o of the pore-water in the top $0.3 \mathrm{~m}$ of soil is lighter suggesting the recycling and dissolution of BSi enriched in ${ }^{28} \mathrm{Si}$. Lugolobi et al. (2010) study the Ge/Si fractionation in the same site and also conclude that biological cycling influence DSi transfer but does not dominate as in Hawaii (see Scenario 2, Derry et al., 2005). The DSi fluxes into the Bay of Bengal, might equal as much as $3.5 \%$ of the global DSi flux into the oceans, are characterized by $\mathrm{Si}$ isotope compositions of groundwater and rivers varying between +1.3 and $-0.2 \%$ o (Georg et al., 2009a). The lighter $\mathrm{Si}$ isotope composition of groundwater might be reflecting the change from primary to secondary $\mathrm{Si}$ sources, mainly clay minerals and silcretes (Basile-Doelsch et al., 2005; Ziegler et al., 2005a; Georg et al., 2009b).

Under these conditions, besides the high mineral Si stock in soils, a high biomass production and turnover should create a relatively large pool of reactive $\mathrm{BSi}$. Indeed, the $\mathrm{BSi}$ accumulation in the soil-plant system is directly governed by the soil weatherable mineral reserves (Henriet et al., 2008a, b). Depending on the type of soil solution (organic layer leachates or mineral soil solutions), the DSi exported from the soil-plant systems could have a biogenic signature in organic soil surface or pedo/lithogenic signature in organomineral and mineral soil (Fig. 3a). Assuming BSi dissolution and secondary precipitate stability, $\mathrm{Si}$ signatures can evolve towards lower $\mathrm{Ge} / \mathrm{Si}$ ratio and $\delta^{30} \mathrm{Si}$ values relatively to the initial Si signature. When dissolution of secondary minerals occurs, the release of light $\mathrm{Si}$ isotopes and $\mathrm{Ge}$ can induce lower $\delta^{30} \mathrm{Si}$ values and higher $\mathrm{Ge} / \mathrm{Si}$ ratios. On the other hand, assuming weathering of primary silicate minerals and formation of secondary precipitates, soil solutions tend to have higher $\delta^{30} \mathrm{Si}$ values and lower $\mathrm{Ge} / \mathrm{Si}$ ratios relatively to the initial Si signature. Related to secondary neoformation and considering identical climatic, geomorphologic and land-use conditions, the lithology of the parental material can also influence the DSi signature exported from soil-plant systems through distinct clay mineralogy (Ziegler et al., 2005b; Cornelis et al., 2010a).

\subsection{Scenario 2: soil weathering-limited}

In a humid tropical environment, the vegetation will increase the chemical weathering rate without increasing the Si removal from the profile towards regional drainage as a result of the transport limited landscape. Alexandre et al. (1997) model that the Si releases from phytolith dissolution is twice that of Si release from silicate weathering. Indeed ecosystems exhibiting strong depletion of mineral-derived $\mathrm{Si}$ and high Si uptake rates by biomass should have a strong biological control on Si cycling and export. In highly weathered soils, with optimal climatic conditions, a large fraction of silicic acid is cycling through plants before its transfer to rivers (Lucas et al., 1993). This implies that the Si concentration of stream water is not controlled by the geochemical processes of the lower soil profile, but rather by the biogeo- chemical cycling within the plant/surface-soil component of the ecosystem (Markewitz et al., 2001). In a tropical rainforest overlying deeply weathered Hawaiian basalt, Derry et al. (2005) established that the Ge/Si ratios of stream waters can be controlled by (i) a Si-rich component with a relatively low $\mathrm{Ge} / \mathrm{Si}$ ratio $\left(\mathrm{Ge} / \mathrm{Si} \sim 0.25 \times 10^{-6}\right)$ derived from dissolution of BSi in upper soil horizons, and (ii) a Si-poor component with a relatively high $\mathrm{Ge} / \mathrm{Si}$ ratio $\left(\mathrm{Ge} / \mathrm{Si} \sim 2.6 \times 10^{-6}\right)$, originating from dissolution of secondary pedogenic minerals. Therefore on a discharge-weighted basis, they found that BSi contributes to $68-90 \%$ of the DSi transported by Hawaiian stream water.

The fact that the solubility of bamboo phytoliths is 17 times greater than quartz (Fraysse et al., 2006) supports recent studies suggesting that the clay mineral stability or formation in the upper soil horizons (Lucas et al., 1993, 2001; Kleber et al., 2007; Opfergelt et al., 2010) are controlled by phytolith production and recycling rather than by dissolution of quartz or other crystalline mineral phases (Barré et al., 2009). The BSi pool potentially controls the DSi in shallow soils (Lucas et al., 1993; Derry et al., 2005), and DSi available for the neoformation of secondary minerals (Opfergelt et al., 2010).

In an environment with very low availability of mineralderived $\mathrm{Si}$ and with significant Si biocycling, we can consider that the DSi fluxes will be highly influenced by the existing BSi pool. Therefore, DSi fluxes in highly weathered systems without BSi recycling will be insignificant compared to the highly weathered systems biologically active. On the other hand, the signature of DSi release (higher $\delta^{30} \mathrm{Si}$ values and lower $\mathrm{Ge} / \mathrm{Si}$ ratios) in those environments can also been influenced by neoformation of secondary clay minerals (relatively higher incorporation of light $\mathrm{Si}$ isotopes and $\mathrm{Ge}$ in clay minerals) (Fig. 3b). Indeed, in intense weathering environment characterized by low weathering rates such as Congo basin (transport-limited regime), $\delta^{30} \mathrm{Si}$ in the river was correlated with weathering intensity rather than $\mathrm{Si}$ fluxes (Cardinal et al., 2010). Silicon isotope signatures in the Congo Basin were controlled by a mixing of both neoformation and dissolution of clay minerals (Cardinal et al., 2010).

The geochemical signatures will therefore be strongly influenced by secondary precipitates: the $\mathrm{Ge} / \mathrm{Si}$ ratio will increase in soil solution if secondary clay-sized mineral dissolution is larger than the $\mathrm{BSi}$ dissolution, and $\delta^{30} \mathrm{Si}$ in soil solution will decrease with both secondary clay-sized mineral and phytolith dissolution since they are both enriched in light $\mathrm{Si}$ isotopes (Fig. 3b).

\subsection{Scenario 3: climate weathering-limited}

It appears that basin lithology and runoff alone are not very reliable indicators of DSi flux in vegetated watersheds where the influence of terrestrial vegetation appears to be important (Fulweiler and Nixon, 2005), promoting silicate weathering and BSi restitution on topsoil. Indeed, the presence of 
coniferous forest with high productivity and significant concentration of $\mathrm{Si}$ in needles can largely contribute to the terrestrial biogeochemical $\mathrm{Si}$ cycle even in temperate climate (Gérard et al., 2008; Cornelis et al., 2010c).

In a French forest site, Bartoli (1983) has estimated that $80 \%$ of DSi exported from the soil profile has been recycled through the BSi pool in deciduous woods, compared to only $20 \%$ in coniferous counterparts. This led Bartoli (1983) to conclude that biocycling of $\mathrm{Si}$ has a substantial impact on DSi sources. Moreover, in central Siberia, besides basaltic bedrocks and soil minerals, the main sources of DSi under permafrost conditions can be the litterfall (3.4 $\left.\mathrm{kg} \mathrm{Si} \mathrm{ha}^{-1} \mathrm{yr}^{-1}\right)$ and subsequent dissolution of phytoliths (Pokrovsky et al., 2005). Similarly, some fraction of the DSi exported from a deforested temperate ecosystem derive from the dissolution of a biologically derived pool of ASi (phytoliths), which supports the impact of Si biocycling in this environment (Conley et al., 2008). In a Bohemian forest, despite lower atmospheric deposition of acids, the higher leaching of DSi in five glacial lakes could be explained by the decline of $\mathrm{Al}$ activity and increase in silicate weathering by BSi dissolution (Veselý et al., 2005). In the wet climate of the Buenos Aires province, ASi from volcanic or biogenic origin is likely responsible for the high concentration of DSi $(1 \mathrm{mM})$ in the shallow groundwater (Miretzky et al., 2001). Moreover, it has been shown that rivers draining areas with carbonate rocks have surprisingly higher DSi fluxes than silicate rocks, which could be attributed to rapid dissolution of disseminated or interbedded BSi of the carbonate rocks (Bluth and Kump, 1994). Finally, Si biocycling is comparable between forests and grasslands on a watershed scale (Table 3). Since grasslands cover about $40 \%$ of terrestrial Earth (White et al., 2000) they likely play an important role in terrestrial Si fluxes, constituting an ideal natural laboratory to use geochemical tracers (Blecker et al., 2007). All these studies, performed in climate weathering-limited environments, support the likely impact of the biological Si cycle on the DSi land-to-river transfer.

In boreal forests, DSi outputs in rivers display lighter $\mathrm{Si}$ isotope composition when the $\mathrm{Si}$-concentration increases (Engström et al., 2010). This suggests the release of isotopically-light plant derived $\mathrm{Si}$ mainly during the spring snowmelt. A large fraction of DSi input to the Baltic Sea was thus assumed to be from biogenic origin (Engström et al., 2010). On the other hand, some of the lowest seasonal $\delta^{30} \mathrm{Si}$ values of the dissolved $\mathrm{Si}$ in some Swiss rivers in high mountain area (Georg et al., 2006) appear to be clearly correlated with high silicate weathering rates. During snowmelt and high river discharge events, elevated $\mathrm{Al}$ concentrations and high base-cation fluxes support a weathering controlled $\mathrm{Si}$ isotope fractionation. A similar isotope systematic, although not as pronounced as in the Swiss study, has been found in rivers all across Iceland (Georg et al., 2007). In Icelandic rivers, dissolved $\mathrm{Si}$ is derived from weathering of basalt and biological effects are absent. The lowest $\delta^{30} \mathrm{Si}$ values coincide with high physical and chemical weathering rates and confirm the observation from the study of Swiss rivers (Georg et al., 2006) that instantaneous silicate weathering rates are inversely correlated with $\delta^{30} \mathrm{Si}$ values. The effect of biogenic recycling superimposed weathering induced fractionation is still to be investigated. In one Swiss river it seems that Si biocycling might actually mitigate weathering induced fractionation to smooth out seasonal isotope trends (Georg et al., 2006). In contrast to Engström et al. (2010) biological recycling has been used to explain unusually high fractionated $\mathrm{Si}$ isotope compositions found in the Asian Yangtze River (up to $+3 \%$, Ding et al., 2004). In the Yangtze, the preferential uptake of light $\mathrm{Si}$ isotopes by rice plant leads to a progressive enrichment of aqueous phase in heavy Si isotopes. Conversely, in the Yellow River in China, the average $\delta^{30} \mathrm{Si}$ value of DSi is $+1.7 \%$ o (Gao et al., 2006) and suggests the impact of the colder weather and lower precipitation in this agriculture area on the decreasing biochemical activity (Ding et al., 2008). However, in these systems, the role of secondary clay-sized mineral formation/dissolution/adsorption on the DSi isotope compositions is not clearly determined, while they play a major role in the DSi signature. Indeed, the Si isotope data combined with the water chemistry of Iceland Rivers show that an average of $50 \%$ of the primary weathered $\mathrm{Si}$ is precipitated into secondary weathering products within the watersheds (Georg et al., 2007). In this climate weathering-limited environment, the DSi load to rivers seems mainly governed by the litho/pedogenic processes such as silicate weathering and clay mineral neoformation. In the Navajo Sandstone aquifer (Arizona, USA), the negative $\delta^{30} \mathrm{Si}$ values $(-1.42 \%$ ) could also be due to dissolution of both secondary clay minerals and low-temperature silcretes (Georg et al., 2009b). In addition, DSi fluxes in Boreal and Artic rivers seem to be influenced by vegetation only through promoting silicate weathering (Humborg et al., 2006b). Similarly, in a temperate granitic forest system, the $\delta^{30} \mathrm{Si}$ values of DSi in surface soil solution (relatively rich in phytoliths) are the most negative never found in natural aqueous system $(-1.38$ and $-2.05 \%$; Cornelis et al., 2010a). The surface soil solution is clearly enriched in Ge with higher $\mathrm{Ge} / \mathrm{Si}$ ratio than the parent material. This finding suggests that forest floor leachate solutions are deeply influenced by the dissolution of ${ }^{28} \mathrm{Si}$ and Ge-enriched secondary clays minerals incorporated by bioturbation in organic-rich horizons, preferentially releasing light $\mathrm{Si}$ isotopes and $\mathrm{Ge}$ (Cornelis et al., 2010a). Besides the impact of Si recycling and restitution of reactive BSi in topsoil, the Si fluxes exported from vegetated areas should be higher than those measured in bare areas (Moulton et al., 2000). In this scenario (Fig. 3c), the DSi exported from the soil profile could have a mix of biogenic and pedo/lithogenic signature. Nevertheless, in some environmental conditions (lithology, geomorphology and land use) and soil horizons, DSi could have specific biogenic or litho/pedogenic signature, hence the interest to combine two geochemical tracers, 
hydrological parameters and water chemistry to understand the origin of pedogenetic processes.

In the specific podzolic case, the signature of DSi in soil solution of the eluvial horizon will not be influenced by pedogenic components, while in the iluvial horizon the geochemical signature of DSi can be influenced by the neoformation (low Ge/Si ratios and high $\delta^{30} \mathrm{Si}$ values in DSi) and dissolution (high Ge/Si ratios and low $\delta^{30} \mathrm{Si}$ values in DSi) of secondary minerals. Assuming no impact of pedogenic components in some specific podzols, the Si signature will be strongly influenced by primary minerals and phytoliths.

At a local scale (pedon, ecosystem), Si isotope values and $\mathrm{Ge} / \mathrm{Si}$ ratios are very helpful to decipher between biological and pedological process impact on the DSi dynamics in the soil-plant system. However, the interpretation of the DSi signature at a regional scale should be performed with caution when the intensity of driving bio/pedo/litho-genic variables is not clearly defined.

\subsection{Scenario 4: weathering-limited}

In African, Arabian, Asian and Australian deserts, Si can be transported through the atmosphere associated with airborne particles that should be the only form of $\mathrm{Si}$ exports from these arid environments (Tegen et al., 2002, 2006). However, since the transport of soil-derived dust in the atmosphere is an effective means of redistributing $\mathrm{Si}$ in the environment, further studies should focus on their signatures $(\mathrm{Ge} / \mathrm{Si}$ ratios and $\delta^{30} \mathrm{Si}$ ) in order to assess their impact on the DSi fluxes following dissolution, which remains poorly investigated (Fig. 3d).

\section{Conclusions}

The origin of DSi exported from a soil-plant system is a dynamic balance between the release of DSi from primary and secondary minerals (litho/pedogenic origin) and from phytoliths (biogenic origin). In tropical environments (Scenarios 1 and 2), DSi fluxes towards rivers are higher compared with climate weathering-limited environments (Scenarios 3 and 4 ). On the other hand, the very low DSi concentration in soil solution of a soil weathering-limited system (Scenarios 2 and 4) is responsible for the low DSi output. Thus, the major load of DSi towards rivers is from the weatheringunlimited system (Scenario 1) where the origin of the $\mathrm{Si}$ sources (litho/pedo or biogenic) needs to be elucidated in a number of experimental sites to better understand the global export of DSi from continents to oceans, and the impact on the global $\mathrm{CO}_{2}$ consumption rates through silicate weathering. In the future, more attention should be given to the systems with high ability for weathering and transport, since the recent studies were focused on the biological control on $\mathrm{Si}$ cycling and export in highly weathered tropical systems with low availability of mineral-derived Si (Scenario 2).
Promising and well-recognized geochemical tracers $\left(\mathrm{Ge} / \mathrm{Si}\right.$ ratios and $\delta^{30} \mathrm{Si}$ ) were shown to represent useful tools for tracing dissolved $\mathrm{Si}$ through the critical zone including the biosphere. However, these tracers unfold their full potential only in conjunction with other geochemical and biochemical data, and are not designed to calculate net Si fluxes exported by vegetation. Geochemical tracers as well as $\mathrm{Si}$ mass-balance calculations at the watershed scale should be implemented in tropical systems in Asia and Oceania displaying the highest DSi fluxes because of their reactive geology, high runoff and high silicate weathering rates. Further studies in mountains areas of high relief would also improve our knowledge about the global impact of the Si-sources on the DSi fluxes towards rivers.

Finally, identifying mechanisms controlling the release of DSi in soil solution in climate weathering-limited environment is of great concern, as global warming is predicted to be most pronounced in high latitudes such as the Arctic environments in North America, Russia and Groenland. It is conceivable that large-scale global change will affect the global Si cycle as a result of temperature and precipitation perturbations. The enrichment of "greenhouse" gases in the atmosphere has led to an increase in the average global surface temperature of $0.6^{\circ} \mathrm{C}$ since the late 19th century (IPCC, 2001), and recent studies show that worldwide fresh water runoff from the continent to the ocean increases through the 20th century because plant transpiration decreases with the elevated atmospheric $\mathrm{CO}_{2}$ (Gedney et al., 2006; Matthews, 2006). As a consequence, since DSi fluxes from continents to oceans are correlated with runoff, temperature and vegetation, we can assume that a change in a climatic variable could disrupt quite rapidly the biogeochemistry of the hydrosphere. DSi fluxes are also influenced by eutrophication and dams providing sedimental burial sites for diatom bloom and trapping of BSi (Humborg et al., 2006a).The geochemical tracers $\left(\mathrm{Ge} / \mathrm{Si}\right.$ ratios and $\left.\delta^{30} \mathrm{Si}\right)$ will help us quantifying anthropogenic and natural variations that should be incorporated into predictive models (Garnier et al., 2006; Bernard et al., 20010) for DSi loads in rivers.

Acknowledgements. J.-T. Cornelis is supported by the "Fonds pour la formation à la Recherche dans l'Industrie et dans l'Agriculture " (FRIA) of Belgium, and S. O. by the "Fonds National de la Recherche Scientifique" (FNRS) of Belgium. This research was also supported by the "Fonds Spécial de Recherche" (FSR) 2008 of the UCL. The authors acknowledge the financial support from the GIP-Ecofor for the management of the Breuil field site, part of the French Ministry of Research "Observatoire de Recherche pour l'Environnement" network. We would like to thank all referees for their constructive comments.

Edited by: C. P. Slomp 


\section{References}

Alexander, G. B., Heston, W. M., and Iler, R. K.: The solubility of amorphous silica in water, Journal of American Chemical Society, 75, 2887, 453-455, 1953.

Alexandre, A., Meunier, J.-D., Colin, F., and Koud, J. M.: Plant impact on the biogeochemical cycle of silicon and related weathering processes, Geochim. Cosmochim. Ac., 61, 677-682, 1997.

Allen, B. L. and Hajek, B. F.: Mineral occurrence in soil environments, in: Minerals in soil environments, Soil Sci. Soc. Am. J., Madison, 199-279, 1989.

Anderson, S. P., Drever, J. I., and Humphrey, N. F.: Chemical weathering in glacial environments, Geology, 25, 399-402, 1997.

Anderson, S. P., Drever, J. I., Frost, C. D., and Holden, P.: Chemical weathering in the foreland of a retreating glacier, Geochim. Cosmochim. Ac., 64, 1173-1189, 2000.

Aoki, Y., Hoshino, M., and Matsubara, T.: Silica and testate amoebae in a soil under pine-oak forest, Geoderma, 142(1-2), 29-35, 2007.

Barman, A. K., Varadachari, C., and Ghosh, K.: Weathering of silicate minerals by organic acids. I. Nature of cation solubilisation, Geoderma, 53, 45-63, 1992.

Barré, P., Berger, G., and Velde, B.: How element translocation by plants may stabilize illitic clays in the surface of temperate soils, Geoderma, 151, 22-30, 2009.

Bartoli, F.: The biogeochemical cycle of silicon in two temperate forest ecosystems, Environ. Biogeochem. Ecol. Bull., 35, 469476, 1983.

Bartoli, F.: Cristallochemistry and surface-properties of biogenic opal, Soil. Sci. Soc. Am. J., 36(3), 335-350, 1985.

Bartoli, F. and Souchier, B.: Cycle et rôle du silicium d'origine végétale dans les écosystèmes forestiers tempérés, Ann. Sci. Forest., 35, 187-202, 1978.

Bartoli, F. and Wilding, L. P.: Dissolution of biogenic opal as a function of its physical and chemical properties, Soil. Sci. Soc. Am. J., 44, 873-878, 1980.

Basile-Doelsch, I., Meunier, J.-D., and Parron, C.: Another continental pool in the terrestrial silicon cycle, Nature, 433, 399-402, 2005.

Beckwith, R. S. and Reeve, R.: Studies on soluble silica in soils. I. The sorption of silicic acid by soils and minerals, Aust. J. Soil Res., 1, 157-168, 1963.

Bélanger, R. R., Bowen, P. A., Ehret, D. L., and Menzies, J. G.: Soluble silicon: its role in crop and disease management of greenhouse crops, Plant Dis., 79, 329-336, 1995.

Bélanger, R. R., Benhamou, N., and Menzies, J. G.: Cytological evidence of an active role of silicon in wheat resistance to powdery mildew (Blumeria graminis f. sp tritici), Phytopathology, 93(4), 402-412, 2003.

Bennet, P. C., Siegel, D. I., Hill, B. M., and Glaser, P. H.: Fate of silicate minerals in a peat bog, Geology, 19, 328-331, 1991.

Bern, C. R., Brzezinski, M. A., Beucher, C., Ziegler, K., and Chadwick, O. A.: Weathering, dust, and biocycling effects on soil silicon isotope ratios, Geochim. Cosmochim. Ac., 74, 876-889, 2010.

Bernard, C. Y., Laruelle, G. G., Slomp, C. P., and Heinze, C.: Impact of changes in river fluxes of silica on the global marine silicon cycle: a model comparison, Biogeosciences, 7, 441-453, doi:10.5194/bg-7-441-2010, 2010.
Berner, R. A.: Chemical weathering and its effect on the atmospheric $\mathrm{CO}_{2}$ and climate, in: Chemical weathering rates of silicate minerals, Reviews in mineralogy, Mineralogical Society of America, Washington, DC, 565-583, 1995.

Berner, R. A.: The rise of plants and their effect on weathering and atmospheric $\mathrm{CO}_{2}$, Science, 276, 544-546, 1997.

Beusen, A. H. W., Bouwman, A. F., Dürr, H. H., Dekkers, A. L. M., and Hartmann, J.: Global patterns of dissolved silica export to the coastal zone: results from a spatially explicit global model, Global Biogeochem. Cy., 23, GB0A02, doi:10.1029/2008GB003281, 2009.

Birchall, J. D.: The role of silicon in biology, Chem. Brit., 26, 141144, 1990.

Blecker S. W., McCulley, R. L., Chadwick, O. A., and Kelly, E. F.: Biologic cycling of silica across a grassland bioclimosequence, Global Biogeochem. Cy., 20, GB3023, doi:10.1029/2006GB002690, 2006.

Blecker, S. W., King, S. L., Derry, L. A., Chadwick, O. A., Ippolito, J. A., and Kelly, E. F.: The ratio of germanium to silicon in plant phytoliths: Quantification of biological discrimination under controlled experimental conditions, Biogeochemistry, 86, 189-199, 2007.

Bluth, G. J. and Kump, L. R.: Lithologic and climatologic controls of river chemistry, Geochim. Cosmochim. Ac., 58, 2341-2359, 1994.

Bormann, B. T., Wang, D., Bormann, F. H., Benoit, G., April, R., and Snyder, M. C.: Rapid, plant-induced weathering in an aggrading experimental ecosystem, Biogeochemistry, 43, 129-155, 1998.

Cardinal, D., Gaillardet, J., Hughes, H. J., Opfergelt, S., and André, L.: Contrasting silicon isotope signatures in rivers from the Congo Basin and the specific behaviour of organic-rich waters, Geophys. Res. Lett., 37, L12403, doi:10.1029/2010GL043413, 2010.

Carnelli, A. L., Madella, M., and Theurillat, J.-P.: Biogenic silica production in selected alpine plant species and plant communities, Ann. Bot., 87, 425-434, 2001.

Carnelli, A. L., Theurillat, J.-P., and Madella, M.: Phytolith types and type-frequencies in subalpine-alpine plant species of the European Alps, Rev. Palaeobot. Palyno., 129, 39-65, 2004.

Cary, L., Alexandre, A., Meunier, J.-D., Boeglin, J.-L., and Braun, J.-J.: Contribution of phytoliths to the suspended load of biogenic silica in the Nyong basin rivers (Cameroon), Biogeochemistry, 74(1), 101-114, 2005.

Casey, W. H., Kinrade, S. D., Knight, C. T. G., Rains, D. W., and Epstein, E.: Aqueous silicate complexes in wheat, Triticum aestivum 1, Plant Cell Environ., 27(1), 51-54, 2003.

Chadwick, O. A., Hendricks, D. M., and Nettleton, W. D.: Silica in duric soils, 2. Mineralogy, Soil Science Society of America Journal, 51(4), 982-985, 1987.

Chadwick, O. A ., Kelly, E. F., Merritts, D. M., and Amundson, R. G.: Atmospheric Carbon Dioxide Consumption During Soil Development, Biogeochemistry, 24, 115-127, 1994.

Chadwick, O. A., Derry, L. A., Vitousek, P. M., Huebert, B. J., and Hedin, L. O.: Changing sources of nutrients during four million years of ecosystem development, Nature, 397, 491-497, 1999.

Chauvel, A., Walker, I., and Lucas, Y.: Sedimentation and pedogenesis in a Central Amazonian Black water basin, Biogeochemistry, 33, 77-95, 1996. 
Clarke, J.: The occurrence and significance of biogenic opal in the regolith, Earth-Sci. Rev., 60, 175-194, 2003.

Cochran, M. F. and Berner, R. A.: Promotion of chemical weathering by higher plants: field observations on Hawaiian basalts, Chem. Geol., 132, 71-77, 1996.

Cocker, K. M., Evans, D. E., and Hodson, M. J.: The amelioration of aluminium toxicity by silicon in higher plants: solution chemistry or an in planta mechanism?, Physiol. Plantarum, 104, 608-614, 1998.

Conley, D. J.: Terrestrial ecosystems and the global biogeochemical silica cycle, Global Biogeochem. Cy., 16(4), 1121, doi:10.1029/2002GB001894, 2002.

Conley, D. J. and Schelske, C. L.: Potential role of sponge spicules in influencing the silicon biogeochemistry of Florida lakes, Can. J. Fish. Aquat. Sci., 50, 296-302, 1993.

Conley, D. J., Sommer, M., Meunier, J.-D., Kaczorek, D., and Saccone, L.: Silicon in the terrestrial biogeosphere, in: The silicon cycle. Human perturbations and impacts on aquatic systems, SCOPE, 66, 13-28, 2006

Conley, D. J., Likens, G. E., Buso, D. C., Saccone, L., Bailey, S. W., and Johnson, C. E.: Deforestation causes increased dissolved silicate losses in the Hubbard Brook Epxerimental Forest, Glob. Change Biol., 14, 2548-2554, 2008.

Conrad, C. F., Icopini, G. A., Yasuhara, H., Bandstra, J. Z., Brantley, S. L., and Heaney, P. J.: Modeling the kinetics of silica nanocolloid formation and precipitation in geologically relevant aqueous solutions, Geochim. Cosmochim. Ac., 71, 531-542, 2007.

Cornelis, J.-T., Delvaux, B., Cardinal, D., André, L., Ranger, J., and Opfergelt, S.: Tracing the mechanisms controlling the release of dissolved silicon in forest soil solutions using $\mathrm{Si}$ isotopes and Ge/Si ratios, Geochim. Cosmochim. Ac., 74, 3913-3924, 2010a.

Cornelis, J.-T., Delvaux, B., and Titeux, H.: The contrasting silicon uptakes by coniferous trees: a hydroponic experiment on young seedlings, Plant Soil, 336, 99-106, $2010 \mathrm{~b}$.

Cornelis, J.-T., Ranger, J., Iserentant, A., and Delvaux, B.: Tree species impact the terrestrial cycle of silicon through various uptakes, Biogeochemistry, 97, 231-245, 2010c.

Cornelis, J.-T., Titeux, H., Ranger, J., and Delvaux, B.: Identification and distribution of the readily soluble silicon pool in a temperate forest soil below three distinct tree species, Plant Soil, doi:10.1007/s11104-010-0702-x, in press, 2011.

Cornell, R. M. and Schwertmann, U.: The Iron Oxides: Structure, Properties, Reactions, Occurence and Uses, VCH, Weinheim and New York, 1996.

Cornu, S., Lucas, Y., Ambrosi, J.-P., and Desjardins, T.: Transfer of dissolved $\mathrm{Al}, \mathrm{Fe}$ and $\mathrm{Si}$ in two Amazonian forest environments in Brazil, Eur. J. Soil Sci., 49, 377-384, 1998.

De La Rocha, C. L., Brzezinski, M. A., and De Niro, M. J.: A first look at the distribution of the stable isotopes of silicon in natural waters, Geochim. Cosmochim. Ac., 64, 2467-2477, 2000.

Delstanche, S., Opfergelt, S., Cardinal, D., Elsass, F., André, L., and Delvaux, B.: Silicon isotopic fractionation during adsorption of aqueous monosilicic acid onto iron oxide, Geochim. Cosmochim. Ac., 73, 923-934, 2009.

Delvigne, C., Opfergelt, S., Cardinal, D., Delvaux, B., and André, L.: Distinct silicon and germanium pathways in the soil-plant system: evidence from banana and horsetail, J. Geophys. Res.Biogeo., 114, G02013, doi:10.1029/2008JG000899, 2009.

Derry, L. A., Kurtz, A. C., Ziegler, K., and Chadwick, O. A.: Bi- ological control of terrestrial silica cycling and export fluxes to watersheds, Nature, 433, 728-731, 2005.

Desplanques, V., Cary, L., Mouret, J.-C., Trolard, F., Bourrié, G., Grauby, O., and Meunier, J.-D.: Silicon transfers in a rice field in Camargue (France), J. Geochem. Explor., 88, 190-193, 2006.

Dietzel, M.: Dissolution of silicates and the stability of polysilicic acid, Geochim. Cosmochim. Ac., 64, 3275-3281, 2000.

Dietzel, M.: Interaction of polysilicic and monosilicic acid with mineral surfaces, in: Water-Rock Interaction, Kluwer Academic Publishers, 207-235, 2002.

Ding, T. P., Wan, D. F., Wang, C., and Zhang, F.: Silicon isotope compositions of dissolved silicon and suspended matter in the Yangtse River, China, Geochim. Cosmochim. Ac., 68(2), 205216, 2004.

Ding, T. P., Ma, G. R., Shui, M. X., Wan, D. F., and Li, R. H.: Silicon isotope study on rice plants from the Zhejiang province, China, Chem. Geol., 218, 41-50, 2005.

Ding, T. P., Zhou, J. X., Wan, D. F., Chen, Z. Y., Wang, C. Y., and Zhang, F.: Silicon isotope fractionation in bamboo and its significance to the biogeochemical cycle of silicon, Geochim. Cosmochim. Ac., 72, 1381-1395, 2008.

Dove, P. M.: Kinetic and thermodynamic controls on silica reactivity in weathering environments, in: Chemical weathering rates of silicate minerals, Mineralogical Society of America and the Geochemical Society, Rev. Mineral. Geochem., 31, 235-290, 1995.

Dove, P. M., Han, N., Wallace, A. F., and De Yoreo, J. J.: Kinetics of amorphous silica dissolution and the paradox of the silica polymorphs, P. Natl. Acad. Sci. USA, 105, 9903-9908, 2008.

Doucet, F. J., Schneider, C., Bones, S. J., Kretchmer, A., Moss, I., Tekely, P., and Exley, C.: The formation of hydroxyaluminosilicates of geochemical and biological significance, Geochim. Cosmochim. Ac., 65, 2461-2467, 2001.

Douthitt, C. B.: The geochemistry of the stable isotopes of silicon, Geochim. Cosmochim. Ac., 46, 1449-1458, 1982.

Drees, L. R., Wilding, L. P., Smeck, N. E., and Senkayi, A. L.: Silica in soils: quartz and disorders polymorphs, in: Minerals in soil environments, Soil Science Society of America, Madison, 914-974, 1989.

Drever, J. I.: The Geochemistry of Natural Waters, Prentice-Hall, Englewood Cliffs, NJ, USA, 1988.

Drever, J. I.: The effect of land plants on weathering rates of silicates minerals, Geochim. Cosmochim. Ac., 58, 2325-2332, 1994.

Dupré, B., Dessert, C., Oliva, P., Goddéris, Y., Viers, J., François, L. M., Millot, R., and Gaillardet, J.: Rivers, chemical weathering and Earth's climate, CR. Geosci., 335, 1141-1160, 2003.

Engström, E., Rodushkin, I., Öhlander, B., Ingri, J., and Baxter, D. C.: Silicon isotopic composition of boreal forest vegetation in Northern Sweden, Chem. Geol., 247, 247-256, 2008.

Engström, E., Rodushkin, I., Ingri, J., Baxter, D. C., Ecke, F., Osterlund, H., and Ohlander, B.: Temporal isotopic variations of dissolved silicon in a pristine boreal river, Chem. Geol., 271, 142-152, 2010.

Epstein, E.: The Anomaly of silicon in plant biology, P. Natl. Acad. Sci. USA, 91, 11-17, 1994.

Epstein, E.: Silicon, Annu. Rev. Plant Phys., 50, 641-664, 1999.

Epstein, E.: Silicon in plants: Facts vs. Concepts, in: Silicon in agriculture, Elsevier, The Netherlands, 1-15, 2001.

Exley, C.: Silicon in life: a bioinorganic solution to bioorganic 
essentiality, J. Inorg. Biochem., 69, 139-144, 1998.

FAO: Global Forest Resources Assessment: progress towards sustainable forest management, Forestry paper 147, Rome, 2006.

Farmer, V. C., Delbos, E., and Miller, J. D.: The role of phytolith formation and dissolution in controlling concentrations of silica in soil solutions and streams, Geoderma, 127, 71-79, 2005.

Faure, G.: Principles and application of inorganic geochemistry, New York, MacMillan, 1991.

Fraysse, F., Pokrovsky, O. S., Schott, J., and Meunier, J.-D.: Surface properties, solubility and dissolution kinetics of bamboo phytoliths, Geochim. Cosmochim. Ac., 70, 1939-1951, 2006.

Fraysse, F., Pokrovsky, O. S., Schott, J., and Meunier, J.-D.: Surface chemistry and reactivity of plant phytoliths in aqueous solutions, Chem. Geol., 258, 197-206, 2009.

Fraysse, F., Pokrovsky, O. S., and Meunier, J.-D.: Experimental study of terrestrial plant litter interaction with aqueous solutions, Geochim. Cosmochim. Ac., 74, 70-84, 2010.

Fulweiler, R. W. and Nixon, S. W. Terrestrial vegetation and the seasonal cycle of dissolved silica in a Southern New England coastal river, Biogeochemistry, 74(1), 115-130, 2005.

Gaillardet, J., Dupré, B., and Allègre, C. J.: A global geochemical mass budget applied to the Congo Basin rivers: Erosion rates and continental crust composition, Geochim. Cosmochim. Ac., 59, 3469-3485, 1995.

Gaillardet, J., Dupré, B., Allègre, C. J., and Négrel, P.: Chemical and physical denudation in the Amazon River Basin, Chem. Geol., 142, 141-173, 1997.

Gaillardet, J., Dupre, B., and Allègre, C. J.: Geochemistry of large river suspended sediments: Silicate weathering or recycling tracer?, Geochim. Cosmochim. Ac., 63(23-24), 40374051, 1999a.

Gaillardet, J., Dupré, B., Louvat, P., and Allègre, C. J.: Global silicate weathering and $\mathrm{CO}_{2}$ consumption rates deduced from the chemistry of large rivers, Chem. Geol., 159, 3-30, 1999b.

Gao, J., Ding, T., and Tian, S.: Silicon isotope compositions of dissolved silicon and suspended matter in the Yellow river, China, Geochim. Cosmochim. Ac., 70(18S), A192, 2006.

Garnier, J., Sferratore, A., Meybeck, M., Billen, G., and Dürr, H.: Modeling silicon transfer processes in river catchments, in: The silicon cycle. Human perturbations and impacts on aquatic systems, SCOPE, 66, 139-162, 2006.

Gedney, N., Cox, P. M., Betts, R. A., Boucher, O., Huntingford, C., and Stott, P. A.: Detection of a direct carbon dioxide effect in continental river runoff records, Nature, 439, 835-838, 2006.

Georg, R. B., Reynolds, B. C., Frank, M., and Halliday, A. N.: Mechanisms controlling the silicon isotopic compositions of river waters, Earth Planet. Sc. Lett., 249, 290-306, 2006.

Georg, R. B., Reynolds, B. C., West, A. J., Burton, K. W., and Halliday, A. N.: Silicon isotope variations accompanying basalt weathering in Iceland, Earth Planet. Sc. Lett., 261, 476-490, 2007.

Georg, R. B., West, A. J., Basu, A. R., and Halliday, A. N.: Silicon fluxes and isotope composition of direct groundwater discharge into the Bay of Bengal and the effect on the global ocean isotope budget, Earth Planet. Sc. Lett., 283, 67-74, 2009a.

Georg, R. B., Zhu, C., Reynolds, B. C., and Halliday, A. N.: Stable silicon isotopes of groundwater, feldspars, and clay coatings in the Navajo Sandstone aquifer, Black Mesa, Arizona, USA, Geochim. Cosmochim. Ac., 73, 2229-2241, 2009b.
Gérard, F., François, M., and Ranger, J.: Processes controlling silica concentration in leaching and capillary soil solutions of an acidic brown forest soil (Rhône, France), Geoderma, 107, 197226, 2002.

Gérard, F., Mayer, K. U., Hodson, M. J., and Ranger, J.: Modelling the biogeochemical cycle of silicon in soils: Application to a temperate forest ecosystem, Geochim Cosmochim Ac., 72(3), 741-758, 2008.

Giesler, R., Ilvesniemi, H., Nyberg, L., van Hees, P., Starr, M., Bishop, K., Kareinen, T., and Lundström, U. S.: Distribution and mobilization of $\mathrm{Al}, \mathrm{Fe}$ and $\mathrm{Si}$ in three podzolic soil profiles in relation to the humus layer, Geoderma, 94, 149-263, 2000.

Gislason, S. R., Oelkers, E. H., Eiriksdottir, E. S., Kardjilov, M. I., Gisladottir, G., Sigfusson, B., Snorrason, A., Elefsen, S., Hardardottir, J., Torssander, P., and Oskarsson, N.: Direct evidence of the feedback between climate and weathering, Earth Planet. Sc. Lett., 277, 213-222, 2009.

Gordeev, V. V., Martin, J. M., Sidorov, I. S., and Sidorova, M. V.: A reassessment of the Eurasian river input of water, sediment, major elements, and nutrients to the Arctic Ocean, Am. J. Sci., 296, 664-691, 1996.

Hammond, K. E., Evans, D. E., and Hodson, M. J.: Aluminium/silicon interactions in barley (Hordeum vulgare L.) seedlings, Plant Soil, 173, 89-95, 1995.

Hartmann, J., Kunimatsu, T., and Levy, J. K.: The impact of Eurasian dust storms and anthropogenic emissions on atmospheric nutrient deposition rates in forested Japanese catchments and adjacent regional seas, Global Planet. Change, 61, 117-134, 2008.

Hartmann, J., Jansen, N., Durr, H. H., Kemp, S., and Kohler, P.: Global $\mathrm{CO}_{2}$-consumption by chemical weathering: what is the contribution of highly active weathering regions?, Global Planet. Change, 69, 185-194, 2009.

Hartmann, J., Jansen, N., Durr H. H., Harashima, A., Okubo, K., and Kempe, S.: Predicting riverine dissolved silica fluxes to coastal zones from a hyperactive region and analysis of their firstorder controls, Int. J. Earth Sci., 99, 207-230, 2010.

Henriet, C., Draye, X., Oppitz, I., Swennen, R., and Delvaux, B.: Effects, distribution and uptake of silicon in banana (Musa spp.) under controlled conditions, Plant Soil, 287, 359-374, 2006.

Henriet, C., De Jaeger, N., Dorel, M., Opfergelt, S., and Delvaux, B.: The reserve of weatherable primary silicates impacts the accumulation of biogenic silicon in volcanic ash soils, Biogeochemistry, 90, 209-223, 2008a.

Henriet, C., Draye, X., Dorel, M., Bodarwe, L., and Delvaux, B.: Leaf silicon content in banana (Musa spp.) reveals the weathering stage of volcanic ash soils in Guadeloupe, Plant Soil, 313, 71-82, 2008 b.

Hiemstra, T., Barnett, M. O., and van Riemsdijk, W. H.: Interaction of silicic acid with goethite, J. Colloid. Interf. Sci., 310(1), 8-17, 2007.

Hinsinger, P., Barros, O. N. F., Benedetti, M. F., Noack, Y., and Callot, G.: Plant-induced weathering of a basaltic rock: experimental evidence, Geochim. Cosmochim. Ac., 65, 137-152, 2001.

Hodson, M. J. and Evans, D. E.: Aluminium/silicon interactions in higher plants, J. Exp. Bot., 46, 161-171, 1995.

Hodson, M. J. and Sangster, A. G.: Aluminium/silicon interactions in conifers, J. Inorg. Biochem., 76(2), 89-98, 1999.

Hodson, M. J., White, P. J., Mead, A., and Broadley, M. R.: 
Phylogenetic variation in the silicon composition of plants, Ann. Bot., 96, 1027-1046, 2005.

Huang, P. M.: Ionic factors affecting the formation of short-range ordered aluminosilicates, Soil Sci. Soc. Am. J., 55, 1172-1180, 1991.

Humborg, C., Pastuszak, M., Aigars, J., Siegmund, H., Morth, C. M., and Ittekkot, V.: Decreased silica land-sea fluxes through damming in the Baltic Sea catchment - significance of particle trapping and hydrological alterations, Biogeochemistry, 77(2), 265-281, 2006a.

Humborg, C., Rahm, L., Smedberg, E., Mörth, C. M., and Danielsson, A.: Dissolved silica dynamics in boreal and arctic rivers: vegetation control over temperature?, in: The silicon cycle. Human perturbations and impacts on aquatic systems, SCOPE, 66, 53-70, $2006 \mathrm{~b}$.

Iler, R. K.: The Chemistry of Silica, Wiley-Interscience, New York, 1979.

Intergovernmental Panel on Climate Change (IPCC): Climate Change: The Scientific Basis, Cambridge Univ. Press, Cambridge, UK, 2001.

IUSS Working Group WRB: World reference base for soil resources 2006, 2nd edn., World Soil Resources Reports No. 103, FAO, Rome, 2006.

Jackson, M. L., Tyler, S. A., Willis, A. L., Bourbeau, G. A., and Pennington, R. P.: Weathering sequence of clay-size minerals in soils and sediments. I. Fundamental generalizations, J. Phys. Colloid. Chem., 52, 1237-1260, 1948.

Jansen, N., Hartmann, J., Lauerwald, R., Duur, H. H., Kempe, S., Loos, S., and Middelkoop, H.: Dissolved silica mobilization in the conterminous USA, Chem. Geol., 270, 90-109, 2010.

Jennerjahn, T. C., Knoppers, B. A., de Souza, W. F. L., Brunskill, G. J., Ivan, E., Silva, L., and Adi, S.: Factors controlling dissolved silica in tropical rivers, in: The silicon cycle. Human perturbations and impacts on aquatic systems, SCOPE, 66, 29-52, 2006.

Jones, L. H. P. and Handreck, K. A.: Effects of iron and aluminum oxides on silica in solution in soils, Nature, 198, 4883, 852-853, 1963.

Jones, L. H. P. and Handreck, K. A.: Studies of silica in the oat plant. III. Uptake of silica from soils by plant, Plant Soil, 23(1), 79-96, 1965.

Jones, L. H. P. and Handreck, K. A.: Silica in soils, plants, and animals, Adv. Agron., 19, 107-149, 1967.

Karathanasis, A. D.: Mineral equilibria in environmental soil systems, in: Soil Mineralogy with environmental applications, Soil Science Society of America, Madison, USA, 109-151, 2002.

Kleber, M., Scwendenmann, L., Veldkamp, E., Röbner, J., and Jahn, R.: Halloysite versus gibbsite: silicon cycling as a pedogenetic process in two lowland neotropical rain forest soils of La Selva, Costa Rica, Geoderma, 138, 1-11, 2007.

Knight, C. T. G. and Kinrade, S. D.: A primer on the aqueous chemistry of silicon, in: Silicon in agriculture, Elsevier, The Netherlands, 57-84, 2001.

Kokfelt, U., Struyf, E., and Randsalu, L.: Diatoms in peat - Dominant producers in a changing environment?, Soil Biol. Biochem., 41, 1764-1766, 2009.

Kokfelt, U., Reuss, N., Struyf, E., Sonesson, M., Rundgren, M., Skog, G., Rosen, P., and Hammarlund, D.: Wetland development, permafrost history and nutrient cycling inferred from late Holocene peat and lake sediment records in subarctic Sweden, J.
Paleolimnol., 44, 327-342, 2010.

Korndörfer, G. H. and Lepsch, I.: Effect of silicon on plant growth and crop yield, in: Silicon in agriculture, Elsevier, The Netherlands, 133-147, 2001.

Kurtz, A. C. and Derry, L. A.: Tracing silicate weathering and terrestrial silica cycling with $\mathrm{Ge} / \mathrm{Si}$ ratios, in: Proceedings of 11th International Symposium on Water Rock Interaction, Leiden, Netherlands, 833-836, 2004.

Kurtz, A. C., Derry, L. A., and Chadwick, O. A.: Accretion of asian dust to Hawaiian soils: isotopic, elemental and mineral mass balances, Geochim. Cosmochim. Ac., 65, 1971-1983, 2001.

Kurtz, A. C., Derry, L. A., and Chadwick, O. A.: Germaniumsilicon fractionation in the weathering environment, Geochim. Cosmochim. Ac., 66, 1525-1537, 2002.

Lal, R.: Soil carbon sequestration impacts on global climate change and food security, Science, 304, 1623-1627, 2004.

Laruelle, G. G., Roubeix, V., Sferratore, A., Brodherr, B., Ciuffa, D., Conley, D. J., Dürr, H. H., Garnier, J., Lancelot, C., Le Thi Phuong, Q., Meunier, J.-D., Meybeck, M., Michalopoulos, P., Moriceau, B., Ní Longphuirt, S., Loucaides, S., Pa push, L., Presti, M., Ragueneau, O., Regnier, P. A. G., Saccone, L., Slomp, C. P., Spiteri, C., and Van Cappellen, P.: Anthropogenic perturbations of the silicon cycle at the global scale: Key role of the land-ocean transition, Global Biogeochem. Cy., 23, GB4031, doi:10.1029/2008GB003267, 2009.

Legros, J. P.: Les Grands Sols du Monde, Presses Polytechniques et Universitaires de Lausanne, 2007.

Liang, Y. C., Yang, C. G., and Shi, H. H.: Effects of silicon on growth and mineral composition of barley grown under toxic levels of aluminium, J. Plant. Nutr., 24, 229-243, 2001.

Liang, Y. C., Sun, W., Zhu, Y. G., and Christie, P.: Mechanisms of silicon-mediated alleviation of abiotic stresses in higher plants: A review, Environ. Pollut., 147, 422-428, 2007.

Lindsay, W. L.: Chemical Equilibria in Soils, Wiley Interscience, New-York, 1979.

Lovering, T. S.: Significance of accumulator plants in rock weathering, Bull. Geol. Soc. Am., 70, 781-800, 1959.

Lucas, Y.: The role of plants in controlling rates and products of weathering: importance of biological pumping, Annu. Rev. Earth Pl. Sc., 29, 135-163, 2001.

Lucas, Y., Luizao, F. J., Chauvel, A., Rouiller, J., and Nahon, D.: The relation between biological activity of the rain forest and mineral composition of soils, Science, 260, 521-523, 1993.

Lugolobi, F., Kurtz, A. C., and Derry, L. A.: Germanium-silicon fractionation in a tropical, granitic weathering environment, Geochim. Cosmochim. Ac., 74, 1294-1308, 2010.

Lux, A., Luxova, M., Abe, J., Morita, S., and Inanaga, S.: Silicifcation of bamboo (Phyllostachys heterocycla mitf.) root and leaf, Plant Soil, 255(1), 85-91, 2003a.

Lux, A., Luxova, M., Abe, J., Tanimoto, E., Hattori, T., and Inanaga, S.: The dynamics of silicon deposition in the sorghum root endodermis, New Phytol., 158(3), 437-441, $2003 \mathrm{~b}$.

Madella, M., Alexandre, A., and Ball, T.: International Code for Phytolith Nomenclature 1.0, Ann. Bot., 96, 253-260, 2005.

Ma, J. F.: Role of silicon in enhancing the resistance of plants to biotic and abiotic stresses, Soil Sci. Plant. Nutr., 50, 11-18, 2004

Ma, J. F. and Takahashi, E.: Soil, fertilizer, and plant silicon research in Japan, Elsevier, The Netherlands, 2002.

Ma, J. F. and Yamaji, N.: Silicon uptake and accumulation in higher 
plants, Trends Plant Sci., 11, 392-397, 2006.

Ma, J. F., Miyake, Y., and Takahashi, E.: Silicon as a beneficial element for crop plants, in: Silicon in agriculture, Elsevier, The Netherlands, 17-39, 2001.

Ma, J. F., Tamai, K., Yamaji, N., Mitani, N., Konishi, S., Katsuhara, M., Ishiguro, M., Murata, Y., and Yano, M.: A silicon transporter in rice, Nature, 440, 688-691, 2006.

Ma, J. F., Yamaji, N., Mitani, N., Tamai, K., Konishi, S., Fujiwara, T., Katsuhara, M., and Yano, M.: An efflux transporter of silicon in rice, Nature, 448, 209-212, 2007.

Markewitz, D. and Richter, D.: The bio in aluminium and silicon geochemistry, Biogeochemistry, 42, 235-252, 1998.

Markewitz, D., Davidson, E. A., Figueiredo, R. O., Victoria, R. L., and Krusche, A. V.: Control of cation concentrations in stream waters by surface soil processes in an Amazonian watershed, Nature, 410, 802-805, 2001.

Marschner, H.: Mineral Nutrition of higher plants, Academic Press, 2nd edn., London, 1995.

Matichenkov, V. V. and Bocharnikova, E. A.: The relationship between silicon and soil physical and chemical properties, in: Silicon in agriculture, Elsevier, The Netherlands, 209-219, 2001.

Matthews, D.: The water cycle freshens up, Nature, 439, 793-794, 2006.

McKeague, J. A. and Cline, M. G.: Silica in soils, Adv. Agron., 15, 339-396, 1963a.

McKeague, J. A. and Cline, M. G.: Silica in soil solutions: II. The adsorption of monosilicic acid by soil and by other substances, Can. J. Soil Sci., 43, 83-96, 1963b.

Meybeck, M.: Concentrations des eaux fluviales en elements majeurs et apports en solution aux oceans, Rev. Geol. Dyn. Geogr., 21, 215-246, 1979.

Meunier, J.-D., Colin, F., and Alarcon, C.: Biogenic silica storage in soils, Geology, 27, 835-838, 1999.

Meunier, J.-D., Alexandre, A., Colin, F., and Braun J.-J.: Intérêt de l'étude du cycle biogéochimique du silicium pour interpréter la dynamique des sols tropicaux, B. Soc. Geol. Fr., 172(5), 533538, 2001

Meunier, J.-D.: Le rôle des plantes dans le transfert du silicium à la surface des continents, CR. Geosci., 335(16), 1199-1206, 2003.

Meunier, J.-D., Guntzer, F., Kirman, S., and Keller, C.: Terrestrial plant-Si and environmental changes, Mineral. Mag., 72, 263$267,2008$.

Michalopoulos, P. and Aller, R. C.: Early diagenesis of biogenic silica in the Amazon delta : alteration, authigenic clay formation and storage, Geochim. Cosmochim. Ac., 68(5), 1061-1085, 2004.

Millot, G.: Les argiles, in: Pour la Science, no. 20, juin, 61-70, 1979.

Milliman, J. D. and Meade, R. H.: World-wide delivery of river sediment to the oceans, J. Geol., 91, 1-21, 1983.

Milliman, J. D. and Syvitski, J. P. M.: Geomorphic/tectonic control of sediment discharge to the ocean: the importance of small mountainous rivers, J. Geol., 100, 525-544, 1992.

Miretzky, P., Conzonno, V., and Fernandez Cirelli, A.: Geochemical processes controlling silica concentrations in groundwaters of the Salado River drainage basin, Argentina, J. Geochem. Explor., 73, 155-166, 2001.

Mitani, N. and Ma, J. F.: Uptake system of silicon in different plant species, J. Exp. Bot., 56, 1255-1261, 2005.
Monger., H. C. and Kelly, E. F.: Silica minerals, in: Soil Mineralogy with environmntal applications, Soil Science Society of America, Madison, USA, 611-636, 2002.

Moulton, K. L., West, J., and Berner, R. A.: Solute flux and mineral mass balance approaches to the quantification of plant effects on silicate weathering, Am. J. Sci., 300, 539-570, 2000.

Murnane, R. J. and Stallard, R. F.: Germanium and silicon in rivers of the Orinoco drainage basin, Nature, 344, 749-752, 1990.

Nagy, K. L.: Dissolution and precipitation kinetics of sheet silicates, in: Chemical weathering rates of silicate minerals, Mineralogical Society of America and the Geochemical Society, Reviews in Mineralogy and Geochemistry, 31, 173-233, 1995.

Oliva, P., Viers, J., Dupré, B., Fortuné, J.-P., Martin, F., Braun, J.-J., Nahon, D., and Robain, H.: The effect of organic matter on chemical weathering: study of a small tropical watershed: Nsimi-Zoétélé site, Cameroon, Geochim. Cosmochim. Ac., 63(23/24), 4013-4035, 1999.

Opfergelt, S., Cardinal, D., Henriet, C., André, L., and Delvaux, B.: Silicon isotope fractionation between plant parts in banana: In situ vs. in vitro, J. Geochem. Explor., 88, 224-227, 2006a.

Opfergelt, S., Cardinal, C., Henriet, C., Draye, X., André, L., and Delvaux, B.: Silicon isotope fractionation by banana (Musa spp.) grown in a continuous nutrient flow device, Plant Soil, 285, 333345, 2006b.

Opfergelt, S., Delvaux, B., André, L., and Cardinal, D.: Plant silicon isotopic signature might reflect soil weathering degree, Biogeochemistry, 91, 163-175, 2008.

Opfergelt, S., de Bournonville, G., Cardinal, D., André, L., Delstanche, S., and Delvaux, B.: Impact of soil weathering degree on silicon isotopic fractionation during adsorption onto iron oxides in basaltic ash soils, Cameroon, Geochim. Cosmochim. Ac., 73, 7226-7240, 2009.

Opfergelt, S., Cardinal, D., André, L., Delvigne, C., Bremond, L., and Delvaux, B.: Variations of $\delta^{30} \mathrm{Si}$ and $\mathrm{Ge} / \mathrm{Si}$ with weathering and biogenic input in tropical basaltic ash soils under monoculture, Geochim. Cosmochim. Ac., 74, 225-240, 2010.

Parfitt, R. L.: Anion adsorption by soils and soil materials, Adv. Agron., 30, 1-50, 1978.

Pédro, G.: Distribution des principaux types d'altération chimique à la surface du globe, Rev. Geogr. Phys. Geol., 5, 457-470, 1968.

Pédro, G.: La genèse des argiles pédologiques, Ses implications minéralogiques, physico-chimiques et hydriques, Sci. Geol. Bull., 37, 333-347, 1984.

Pearsall, D. M. and Piperno, D. R.: Current research in phytolith analysis: Applications in archaeology and paleoecology, Masca Research Papers in Science and Archaeology, 10, 212 pp., 1993.

Perry, C. C. and Keeling-Tucker, T.: Aspects of the bioinorganic chemistry of silicon in conjunction with the biometals calcium, iron and aluminium, J. Inorg. Biochem., 69, 181-191, 1998.

Piperno, D. R.: Phytolith Analysis: An Archaeological and Geological Perspective, Academic Press, San Diego, 280 pp., 1988.

Piperno, D. R. and Stothert, K. E.: Phytolith evidence for early Holocene cucurbita domestication in southwest Ecuador, Science, 299, 1054-1057, 2003.

Pokrovsky, G. S., Schott, J., Garges, F., and Hazemann, J. L.: Iron (III)-silica interactions in aqueous solution: Insights from X-ray absorption fine structure spectroscopy, Geochim. Cosmochim. Ac., 67(19), 3559-3573, 2003.

Pokrovsky, O. S, Schott, J., Kudryavtzev, D. I., and Dupré, B.: 
Basalt weathering in Central Siberia under permafrost conditions, Geochim. Cosmochim. Ac., 69(24), 5659-5680, 2005.

Rafi, M. M., Epstein, E., and Falk R. H.: Silicon deprivation causes physical abnormalities in wheat (Triticum aestivum L.), J. Plant Phys., 151, 497-501, 1997.

Ragueneau, O., Conley, D. J., Leynaert, A., Longphuirt, S. N., and Slomp, C. P.: Responses of coastal ecosystems to anthropogenic perturbations of silicon cycling, in: The silicon cycle. Human perturbations and impacts on aquatic systems, SCOPE, 66, 197214, 2006.

Rai, D. and Kittrick, J. A.: Mineral equilibria and the soil system, in: Minerals in Soil Environments, Soil Science Society of America, Madison, USA, 161-198, 1989.

Raven, J. A.: The transport and function of silicon in plants, Biol. Rev., 58, 179-207, 1983

Raven, J. A.: Silicon transport at the cell and tissue level, in: Silicon in agriculture, Elsevier, The Netherlands, 41-55, 2001.

Raymo, M. E., Ruddiman, W. F., and Froelich, P. N.: Influence of late Cenozoic mountain building on ocean geochemical cycles, Geology, 16, 649-653, 1988.

Richmond, K. E. and Sussman, M.: Got silicon? The non-essential beneficial plant nutrient, Curr. Opin. Plant Biol., 6(3), 268-272, 2003.

Saccone, L., Conley, D. J., Koning, E., Sauer, D., Sommer, M., Kaczorek, D., Blecker, S. W., and Kelly, E. F.: Assessing the extraction and quantification of amorphous silica in soils of forest and grassland ecosystems, Eur. J. Soil Sci., 58, 1446-1459, 2007.

Saccone, L., Conley, D. J., Likens, G. E., Bailey, S. W., Buso, D. C., and Johnson, C. E.: Factors that control the range and variability of amorphous silica in soils in the Hubbard Brook experimental Forest, Soil Sci. Soc. Am. J., 72, 1637-1644, 2008.

Sangster, A. G. and Hodson, M. J.: Silica in higher plants, in: Silicon Biochemistry, Ciba Foundation Symposium, John Wiley, Chichester, 90-107, 1986.

Sangster, A. G., Hodson, M. J., and Tubb, H. J.: Silicon deposition in higher plants, in: Silicon in Agriculture, Elsevier, The Netherlands, 85-113, 2001.

Sauer, D., Saccone, L., Conley, D. J., Herrmann, L., and Sommer, M.: Review of methodologies for extracting plant-available and amorphous Si from soils and aquatic sediments, Biogeochemistry, 80, 89-108, 2006.

Schoelynck, J., Bal, K., Backx, H., Okruszko, T., Meire, P., and Struyf, E.: Silica uptake in aquatic and wetland macrophytes: a strategic choice between silica, lignin and cellulose?, New Phytol., 186, 385-391, 2010.

Schwertmann, U. and Taylor, R. M.: Iron oxides, in: Minerals in soil environments, Soil Science Society of America, Madison, USA, 379-438, 1989.

Scribner, A. M., Kurtz, A. C., and Chadwick, O. A.: Germanium sequestration by soil: Targeting the roles of secondary clays and Fe-oxyhydroxides, Earth Planet. Sc. Lett., 243, 760-770, 2006.

Siever, R. and Woodford, N.: Sorption of silica by clay minerals, Geochim. Cosmochim. Ac., 37, 1851-1880, 1973.

Simonson, R. W.: Airborne dust and its significance to soils, Geoderma, 65, 1-43, 1995.

Smetacek, V.: Diatoms and the ocean carbon cycle, Protist, 150, 25-32, 1999.

Smithson, F.: Plant opal in soil, Nature, 178, p. 107, 1956.

Sommer, M., Kaczorek, D., Kuzyakov, Y., and Breuer, J.: Silicon pools and fluxes in soils and landscapes-a review, J. Plant Nutr. Soil Sci., 169, 310-329, 2006.

Street-Perrott, F. A. and Barker, P.: Biogenic silica: a neglected component of the coupled global continental biogeochemical cycles of carbon and silicon, Earth Surf. Proc. Land, 33, 14361457, 2008.

Struyf, E. and Conley, D. J.: Silica: an essential nutrient in wetland biogeochemistry, Front. Ecol. Environ., 7(2), 88-94, 2009.

Struyf, E., van Damme, S., Gribsholt, B., Bal, K., Beauchard, O., Middelburg, J. J., and Meire, P.: Phragmites australis and Si cycling in tidal wetlands, Aquat. Bot., 87, 134-140, 2007.

Struyf, E., Opdekamp, W., Backx, H., Jacobs, S., Conley, D. J., and Meire, P.: Vegetation and proximity to the river control amorphous silica storage in a riparian wetland (Biebrza National Park, Poland), Biogeosciences, 6, 623-631, doi:10.5194/bg-6623-2009, 2009.

Struyf, E., Smis, A., van Damme, S., Garnier, J., Govers, G., van Wesemael, B., Conley, D. J., Batelaan, D., Frot, E., Clymans, W., Vandevenne, F., Lancelot, C., Goos, P., and Meire, P.: Historical land use change has lowered terrestrial silica mobilization, Nat. Commun., 1, 129, doi:10.1038/ncomms1128, 2010.

Summerfield, M. A. and Hulton, N. J.: Natural controls of fluvial denudation rates in major world drainage basins, J. Geophys Res., 99(B7), 13871-13883, doi:10.1029/94JB00715, 1994.

Takahashi, E., Ma, J. F., and Miyake, Y.: The possibility of silicon as an essential element for higher plants, Comments Agric. Food. Chem., 2, 99-122, 1990.

Tegen, I. and Kohfeld, K. E.: Atmospheric transport of silicon, in: The silicon cycle. Human perturbations and impacts on aquatic systems, SCOPE, 66, 81-92, 2006.

Tegen, I., Harrison, S. P., Kohfeld, K. E., Prentice, I. C., Coe, M. C., and Heimann, M.: The impact of vegetation and preferential source areas on global dust aerosol: Results from a model study., J. Geophys. Res., 107, 4576, doi:10.1029/2001JD000963, 2002.

Torn, M. S., Trumbore, S. E., Chadwick, O. A., Vistousek, P. M., and Hendricks, D. M.: Mineral control of soil organic carbon and turnover, Nature, 389, 170-173, 1997.

Tréguer, P. and Pondaven, P.: Silica control of carbon dioxide, Nature, 406, 358-359, 2000.

Tréguer, P., Nelson, D. M., Van Bennekom, A. J., De Master, D. J., Leynaert, A., and Quéguiner, B.: The silica balance in the world ocean: a reestimate, Science, 268, 375-379, 1995.

Turner, R. E., Rabalais, N. N., Justic, D., and Dortch, Q.: Global patterns of dissolved N, P and Si in large rivers, Biogeochemistry, 64, 297-317, 2003.

Van Cappellen, P.: Biomineralization and global biogeochemical cycles, Rev. Mineral. Geochem., 54, 357-381, 2003.

Veselý, J., Majer, V., Kopácek, J., Safanda, J., and Norton, S. A.: Increasing silicon concentrations in Bohemian Forest lakes, Hydrol. Earth Syst. Sci., 9, 699-706, doi:10.5194/hess-9-699-2005, 2005.

Vuai, S. A. H. and Tokuyama, A.: Solute generation and $\mathrm{CO}_{2}$ consumption during silicate weathering under subtropical, humid climate, northern Okinawa Island, Japan, Chem. Geol., 236, 199-216, 2007.

Wada, K.: Allophane and imogolite, in: Minerals in Soil Environments, Soil Science Society of America, Madison, USA, 10511087, 1989.

Wedepohl, K. H.: The composition of the continental crust, 
Geochim. Cosmochim. Ac., 59, 1217-1232, 1995.

White, A. F.: Chemical weathering rates of silicate minerals in soils, in: Chemical weathering rates of silicate minerals, Mineralogical Society of America and the Geochemical Society, Reviews in Mineralogy and Geochemistry, 31, 407-460, 1995.

White, A. F. and Blum, A. E.: Effects of climate on chemical weathering in watersheds, Geochim. Cosmochim. Ac., 59, 1729-1747, 1995.

White, R., Murray, S., and Rohweder, M.: Pilot analysis of global ecosystems: Grassland ecosystems, report, World Resour. Inst., Washington D.C., 81 pp., 2000.

Wilding, L. P. and Drees, L. R.: Contributions of forest opal and associated crystalline phases to fine silt and clay fractions of soils, Clay. Clay Miner., 22, 295-306, 1974.
Wüst, R. A. J. and Bustin, R. M.: Opaline and Al-Si phytoliths from a tropical mire system of West Malaysia: abundance, habit, elemental composition, preservation and significance, Chem. Geol., 200, 267-292, 2003.

Yamaji, N., Mitani, N., and Ma, J. F.: A transporter regulating silicon distribution in rice shoots, Plant Cell, 20, 1381-1389, 2008.

Ziegler, K., Chadwick, O. A., Brzezinski, M. A., and Kelly, E. F.: Natural variations of $\delta^{30} \mathrm{Si}$ ratios during progressive basalt weathering, Hawaiian Islands, Geochim. Cosmochim. Ac., 69, 4597-4610, 2005a.

Ziegler, K., Chadwick, O. A., White, A. F., and Brzezinski, M. A.: $\delta^{30} \mathrm{Si}$ systematics in a granitic saprolite, Puerto Rico, Geology, 33, 817-820, 2005b. 